Graduate Institute of

International and Development Studies Working Paper

No: $16 / 2010$

\title{
The Federal Reserve, the Bank of England, and the Rise of the Dollar as an International Currency, 1914-1939
}

\author{
Barry Eichengreen \\ University of California, Berkeley \\ Marc Flandreau \\ Graduate Institute of International Studies
}

\begin{abstract}
This paper provides new evidence on the rise of the dollar as an international currency, focusing on its role in the conduct of trade and the provision of trade credit. We show that the shift to the dollar occurred much earlier than conventionally supposed: during and immediately after World War I. Not just market forces but also policy support - the Fed in its role as market maker - was important for the dollar's overtaking of sterling as the leading international currency. On balance, this experience challenges the popular notion of international currency status as being determined mainly by market size. It suggests that the popular image of strongly increasing returns and pervasive network externalities leaving room for only one monetary technology is misleading.
\end{abstract}

(C) The Authors.

All rights reserved. No part of this paper may be reproduced without the permission of the authors. 


\title{
The Federal Reserve, the Bank of England, and the Rise of the Dollar as an International Currency, 1914-1939 ${ }^{1}$
}

\author{
Barry Eichengreen and Marc Flandreau
}

August 2010

\begin{abstract}
This paper provides new evidence on the rise of the dollar as an international currency, focusing on its role in the conduct of trade and the provision of trade credit. We show that the shift to the dollar occurred much earlier than conventionally supposed: during and immediately after World War I. Not just market forces but also policy support - the Fed in its role as market maker - was important for the dollar's overtaking of sterling as the leading international currency. On balance, this experience challenges the popular notion of international currency status as being determined mainly by market size. It suggests that the popular image of strongly increasing returns and pervasive network externalities leaving room for only one monetary technology is misleading.
\end{abstract}

\footnotetext{
1. Barry Eichengreen is George C. and Helen N. Pardee Professor of Economics and Political Science at the University of California, Berkeley. Marc Flandreau is Professor of International History and International Economics at the Graduate Institute of International Studies and Development, Geneva. This paper received funding from the National Science Foundation and the Fondation Banque de France pour la Recherche whose generous support is gratefully acknowledged. Many thanks to Olivier Accominotti, Gopalan Balachandran, Peter Ferderer and John James for their generosity in sharing with us data and insights. They are of course absolved from shortcomings that can only be ours. We are grateful to Hassan Malik, Riad Rezzik, Trevin Stratton, Pierre Turgeon for assisting with the data collection. Many thanks also to Sara and Théa Bertin for their friendly help with spotting material in the New York Public Library. This paper benefited comments from participants to $8^{\text {th }}$ Journées of the Foundation Banque de France, 21-22 June 2010, and to the BIS annual research conference, Lucerne, 24-25 June 2010. Comments and suggestions by our discussant and from Philip Lane are gratefully acknowledged.
} 
In this paper we consider the role of central banks in shaping financial structures and building financial markets, and how their actions can have implications for the place of those markets in the world. The case on which we focus is the making of a market in dollardenominated trade credits - the instruments known as "bankers' acceptances" - in the early $20^{\text {th }}$ century.

This case speaks to several issues that arise in connection with central banking and monetary policy today. A first issue concerns the role of policy, and specifically central bank policy, in fostering local-currency securities markets. Since the financial crises of the 1990s, Asian and Latin American countries have made concerted efforts to develop markets in debt instruments denominated in local currency as a way of limiting the currency mismatches that are a source of financial fragility. Governments have issued a range of maturities in the effort to establish benchmark yield curves. Central banks have intervened in the secondary market to provide liquidity. While there has been progress in developing local markets, achievement has not always matched aspiration, especially where internationally-traded debt securities are concerned. ${ }^{2}$ Our historical case, where the United States itself sought to solve the same problem, sheds historical light on this current policy issue.

A second topic to which our analysis speaks is international currency competition. It is widely argued that there is only room for one international currency in the global system. The theoretical assertion is that increasing returns to using a national currency in international transactions are strong; network externalities are pronounced. The empirical assertion is that the pound sterling dominated international transactions in the first half of the $20^{\text {th }}$ century, the dollar in its second half. In recent work we have shown that this last assertion is not accurate for foreign-exchange reserves. Sterling and the dollar in fact shared the reserve-currency role more or less equally in the 1920 s and 1930s. ${ }^{3}$

From a theoretical point of view, it can be objected that network effects are weaker for international reserves than other international currency functions. While it pays to for importers and exporters use the same currency as other importers and exporters when, inter alia, invoicing and settling trade, a central bank has no similar incentive to concentrate its reserve portfolio in the same currency as other central banks; to the contrary, it will have an incentive to hold a diversified portfolio of reserves. But here we show that what was true of international reserves (that is, of official use) prior to 1914 was also true trade credit (of private use). For the bankers' acceptances used for trade credit, just as for international reserves, sterling and the dollar shared the market.

For those who wish to draw an implication for the $21^{\text {st }}$ century, it is that network effects giving rise to increasing returns have limits. ${ }^{4}$ There is no reason therefore why the dollar and the euro, notwithstanding their respective recent difficulties, cannot both be consequential international currencies.

\footnotetext{
${ }^{2}$ On the evidence, see Hausmann and Panizza (2010).

${ }^{3}$ Something that has obvious implications for thinking about the future. The recent work in question is Eichengreen and Flandreau (2009).

${ }^{4}$ Here we echo a point made by Liebowitz and Margolis (1990) in another context.

${ }^{5}$ Or why other currencies could not eventually join them.
} 
Related to this is the question of how quickly we should expect China's currency to gain an important international role. As we show, the United States went in only ten years from a position where the dollar had no place as an international currency and New York was a negligible source of finance for international trade to one where the dollar was at least sterling's coequal and New York rivaled London as a source of trade credit. ${ }^{6}$ This is not to assert that the renminbi will necessarily rival the dollar and the euro in 2020. But it does suggest that, if network effects are less powerful than commonly asserted, the renminbi's emergence may be quicker than widely presumed.

Our evidence also highlights the regional dimension of international currency competition. ${ }^{7}$ In the second and third decades of the $20^{\text {th }}$ century, U.S. banks and bankers' acceptances followed U.S. trade, and U.S. trade followed the laws of gravity. ${ }^{8}$ Foreign branching by U.S. banks occurred predominantly in places like Latin America where U.S. trade, for reasons of geography, was most extensive. This gives grounds for thinking that the renminbi's role as an invoicing and settlement currency and China's as a source of trade finance will be greatest in Asia, where its trade will grow most rapidly.

Finally, there is concern that central banks' extraordinary actions in 2007-9, taken to provide liquidity to distressed financial markets by purchasing commercial paper, mortgagebacked securities and other financial assets outright, created a reservoir of inflationary pressure that will burst when bank lending picks up (in clear, central banks' market-making and marketsupporting actions would have created a conflict with their price stability mandate). There are fears that central bank action created a new credit bubble destined to burst, and that their interventions merely disguise problems that will become acute once they exit. There is concern about crowding out: central banks' readiness to step in as market makers of last resort may discourage other buyers from reentering the market. There is concern that the indiscriminate purchase of securities by central banks will encourage the renewed issuance of financial instruments of dubious quality, setting the stage for another round of financial excesses and problems. We note that the same criticisms were levied against central banks' market-making activities in the 1920s. ${ }^{9}$ While we do not have definitive answers to all these questions, we offer some food for thought.

The remainder of the paper is organized as follows. In Section 1 we provide some historical and institutional background on the case in question. Section 2 then focuses on the transitional period. It shows how dollar acceptances as an instrument for trade finance expanded rapidly in the 1920s from a position of, essentially, nonexistence in 1914. It highlights the actions of the Federal Reserve in promoting the rise of the market. Section 3 turns next to the position of the incumbent, sterling. We present new evidence showing that sterling shared the status of international currency with the dollar all through the 1920s.

\footnotetext{
${ }^{6}$ With some exaggeration, Alexander Noyes, financial editor of the New York Times, argued that the replacement of London by New York and of sterling by the dollar occurred "almost immediately" with the outbreak of World War I (Silber 2007, p.168).

${ }^{7}$ See Flandreau and Jobst (2009), who document the influence of trade and geography on currency internationalization before World War I.

${ }^{8}$ That is to say, it flowed in the directions and proportions suggested by the gravity model of international trade.

${ }^{9}$ See Rothbard (1963), pp.117-123.
} 
Section 4, finally, reports evidence on the determinants of individual American banks' position in the acceptance market. It allows us to assess the relative importance of market forces, meaning trade and the general economic environment, and public policy initiatives, meaning the support from, or "private-public partnership" with, the Federal Reserve, in the growth of the market.

We conclude with a summary and some implications for today.

\section{Background}

Exporters need credit to purchase materials and pay their bills while their merchandise is in transit and payment has not been received. Typical practice prior to 1913 was for an American exporter would go to his bank with documents showing that he had shipped the goods and indicating what he would be paid in the future. If his collateral and credit were good, he could get his money immediately rather than having to wait for the goods to arrive in the foreign market and the buyer's payment to then arrive in the United States.

His bank financed the operation by drawing on a correspondent (or "acceptor") with which it had made prior arrangement. Upon receipt of the bill, which specified the commodities shipped and the name of the drawer (the U.S. bank), the correspondent whose name was mentioned in the document "accepted" the security. The resulting instruments were thus known as "acceptances." Triply guaranteed by the goods, by the drawer, and by the acceptor, they could be sold on to other investors. A simple bank-to-customer credit was thereby transformed into a liquid, tradable instrument.

U.S. exports grew faster than those of any other nation in the decades leading up to World War I. By 1912 the United States was the leading trading nation. It is thus striking that virtually no trade credit was provided by U.S. banks or denominated in dollars. Instead, American banks seeking to provide these services did so through correspondent banks in London. These acceptances were denominated in sterling, since that was the currency with which the London banks, the secondary-market investors to whom they sold the paper, and the Bank of England were all accustomed.

The London market had a number of strengths. ${ }^{10}$ It had a well-developed population of banks, generically referred to as merchant banks for their origins in helping merchants with the finance of trade in the early $19^{\text {th }}$ century. ${ }^{11}$ Possessing networks of overseas correspondents, they were able to originate a large volume of acceptances. ${ }^{12}$ Having originated acceptances, the banks turned around and distributed this paper on a large secondary market of individual and institutional investors. They could distribute the acceptances to the market either individually or in bulk (in packages known as "parcels") through the agency of bill brokers. ${ }^{13}$ In the unusual

\footnotetext{
${ }^{10}$ As contemporaries such as Jacobs (1910) recognized.

${ }^{11}$ And also private, joint stock and colonial institutions with international reach.

${ }^{12}$ Over time, the large commercial banks with their substantial international branch networks joined them.

${ }^{13}$ See King (1936).
} 
event that there was no ready purchaser, they could offload them to the Bank of England at "Bank rate."14

This trio of factors - Britain's early start as a trading nation, resulting in the merchant banks' first-mover advantage; a large and active secondary market; and a market-maker of last resort - made for low costs and strongly increasing returns. They explain why London monopolized the provision of trade credit and why sterling was the dominant international currency. They explain why New York and the dollar played no international role. There was room for only one international currency, it is said. And sterling, with its first-mover advantage, was it. ${ }^{15}$

But another interpretation of why New York could not break into the market is that regulatory prohibitions and not increasing returns prevented U.S. banks from entering. Under the National Banking Act, American banks were prohibited from branching abroad. ${ }^{16}$ Federal legislation prevented banks from dealing in trade acceptances. ${ }^{17}$ And the U.S. lacked a central bank to backstop the market. Given this, it is hardly surprising that the dollar played no international role.

Two bits of circumstantial evidence are consistent with the alternative view that increasing returns and network effects were limited and that there was room in the market for more than one international currency. First, foreign exchange trading and trade finance went

\footnotetext{
${ }^{14}$ They could also secure advances from the central bank against the parcels.

${ }^{15}$ This narrative was prominent in the debates surrounding the creation of the Federal Reserve System. In a pamphlet written for National Monetary Commission, for example, Jacobs (1910, p. 13) deplored a state of affairs in which U.S. bankers were forced to transact via London, observing how this "adds to the importance of London and militates against the development of New York as a financial center." John J. Arnold, First Vice-President of the First National Bank of Chicago, similarly argued that the "three cornered arrangement" whereby London banks financed American foreign trade could "and should be eliminated" so that a "direct dollar exchange market" be created between the US and South America and the Orient so as to deny London "the undue advantage which this center has had in the past" (Parrini 1968, p. 105). U.S. business and policy leaders supporting the internationalization of New York and the U.S. dollar referred to the amount paid annually to British banks in acceptance fees as the "tribute" (see e.g. Warburg 1910). Of course the metaphor was flawed: British bankers financed American trade more cheaply than New York bankers would have (Phelps 1927, p. 102; Parrini 1968, p. 103). The actual amount involved was a small fraction of U.S. trade or GDP. In 1927, when U.S. banks had secured a large share of the global market for acceptances, the Acceptance Bulletin estimated the annual saving to have been a "material" $\$ 5$ million. Even this figure is an upper bound, since it does not subtract the resource cost for U.S. banks to supply the acceptances.

${ }^{16}$ Trust companies could branch abroad, but few did, and those which set up foreign offices did so mainly in order to gather information on foreign bonds, which were attractive assets to add to their portfolios since these matched the maturity of their liabilities to their trustees. Some state-charters also allowed state banks to branch abroad, although few if any ever did. There was one specialized institution, the International Banking Corporation, set up by the Remington Arms Company to assist it in its foreign sales, that operated foreign branches but was prohibited from engaging in domestic banking.

${ }^{17}$ Actually the relevant legislation only lacked provisions explicitly authorizing banks to engage in this business, but the courts, channeling long-standing American suspicion of concentrated financial power, repeatedly ruled against their efforts to do so. While other forms of short term credit emerged, they were less liquid than European style acceptances. One form of short-term negotiable security that came to existence and played some domestic role was the so-called single name "commercial paper." Commercial paper was issued by industrial and commercial enterprises of substantial standing and traded in organized markets. But while commercial paper paid with "clockwork regularity," it was relatively illiquid (James 1995, p. 224, drawing on Foulke 1931, pp.80, 84-6).
} 
hand in hand, and sterling did not monopolize foreign exchange trading. ${ }^{18}$ Second, the use of a currency as central bank reserves and in foreign trade and payments went together, smoothing trade and payments being one reason why central banks hold reserves, and sterling by no means monopolized foreign exchange reserves. ${ }^{19}$ This is consistent with the presumption that sterling was the leading international currency. But it is inconsistent with the belief that it was the only one.

Second, the evidence in Flandreau and Jobst (2009) is inconsistent with strongly increasing returns. The authors construct a model of the pre-1914 international monetary system that allows for strategic externalities. Currencies are traded abroad as a function of their value for users. Value is greater when currencies are liquid. This encourages more users to hold liquid currencies and generates positive feedback. Persistence emerges when the feedback loop is sufficiently powerful. Flandreau and Jobst estimate this model using pre-1914 data and reject the presence of strong lock-in effects. These findings thus cast doubt on popular notions of network externalities being an insurmountable obstacle to the rise of the dollar.

The 1920s permit a more direct test. The Federal Reserve Act of 1913 created a U.S. central bank authorized to discount and purchase trade acceptances as a mechanism for smoothing interest rates and managing credit conditions. It removed the prohibition on foreign branching and authorized banks to deal in trade acceptances. ${ }^{20}$ World War I then disrupted the provision of trade credit by London and the other European financial centers, giving the New York market an opportunity to get up and running.

One can thus imagine three hypotheses for what one should expect to see in the 1920s.

- Network effects and increasing returns were sufficiently powerful that London retained its first mover advantage. Lock-in being strong, the equilibrium would not shift even if an alternative was more efficient for the world as a whole. ${ }^{21}$

- While network effects and increasing returns were strong, central banks as architects could shift the system between equilibria. Although New York

\footnotetext{
${ }^{18}$ Flandreau and Jobst (2005) show that bills denominated in sterling, francs and marks had the widest foreign circulation. Those in sterling were traded everywhere, those in francs in 80 per cent of foreign markets, those in German marks in 59 per cent.

${ }^{19}$ According to Lindert (1969), sterling accounted for 51 per cent of identified reserves in 1913, the franc 33 per cent, the mark 16 per cent.

${ }^{20}$ One motive for the act was precisely to create a market in trade acceptances in New York, the belief being that a market in securities backed by receivables would be more stable than one dominated by speculative stock market transactions - this having been a popular explanation for the 1907 financial crisis.

${ }^{21}$ This is essentially the QWERTY story of strong lock-in (David 1985). This presumption is found in some recent historical literature in which it is argued that sterling remained the leading international currency until after World War II as well as in accounts by economists. Modern accounts assert that, once established, London's firstmover advantage was difficult, even impossible to overturn. For example, Roberts and Kynaston (2000, p.192) argue that "the lesson of history is that - once established - leading financial centers retain their primacy until toppled by an external shock." Michie (2007, p. 78) similarly argues that World War I was a major shock for London's supremacy, but was "insufficient to destroy the strong position it had established in the years before 1914." Others like Aliber (1968) and, more recently, Chinn and Frankel (2008), have echoed Triffin (1960) in suggesting that dollar only overtook sterling after World War II.
} 
lacked a secondary market of individual and institutional investors for much of the period, the Fed provided resources to shift to the new equilibrium (a policy analogous to "big push" in models of underdevelopment with multiple equilibria). The Fed acted as market maker of last resort, allowing the dollar to supplant sterling as the currency used for trade finance already in the $1920 \mathrm{~s}^{22}$

- Increasing returns were not strong enough to give one currency a natural monopoly, and network effects were not sufficiently pervasive for strong lockin. As a result of both market forces and policy intervention, monopoly gave way to duopoly. Sterling and the dollar could and did share the international currency role in the 1920s.

\section{The Rise of New York}

The Federal Reserve System played a key role in fostering the international role of the dollar. It did so as a carrier of regulatory reform. But, in addition, it actively promoted the new market. ${ }^{23}$

Figure 1 uses interest rates to measure the competitiveness of the London and New York markets. While the cost of acceptance credit had other components (taxes, the bank's commission, exchange risk insurance etc.), the interest rate was the largest part. ${ }^{24}$ The rate for London is the open market rate - the rate at which acceptances were bought by investors. We compare it to the open market rate on U.S. acceptances when possible. But since U.S. rates for acceptances only become available in January 1917, we also show prime U.S. commercial paper rates (i.e. the rate on prime short-term credit instruments issued by corporate borrowers of high standing), which begin earlier. ${ }^{25}$

\footnotetext{
${ }^{22}$ Previous students of strategic externalities (Liebowitz and Margolis 1990) have argued in that the strong lock-in suggested by the QWERTY hypothesis is unlikely. In the conventional tale, large players are able to subsidize adoption of the new standard and, once it is adopted, agents coordinate on it and the subsidy is no longer needed. In our context, these players would be central banks or possibly public-private partnership of banks and policy makers. In this spirit, Ferderer (2003, p.666) argues that "Federal Reserve Banks played a key role by reducing the risk borne by private dealers and propelling the [dollar acceptances] market to a high-liquidity equilibrium." Silber (2007, p.168) praises the steps taken by Treasury Secretary McAdoo at the onset of World War I to keep the dollar onto gold, persuading markets of its credibility. Had this policy not been implemented, he concludes, "Britain could have easily remained the undisputed, if somewhat battered, champion of international finance until the Second World War. It almost happened."

${ }^{23}$ While the first effect was permanent, the second was more transient, the Fed withdrawing from the market after the summer of 1931 .

${ }^{24}$ This makes the interest differential a fair approximation of the relative cost of financing a shipment in the alternative centers and currencies. See Velay (1932), p. 121.

${ }^{25}$ This is an appropriate comparison, since commercial paper benefited in similar fashion from the new arrangements. The Federal Reserve Act was intended to promote the commercial paper market, and Federal Reserve rediscount rates on commercial paper were close to, if slightly higher than, the rate on acceptances. As recalled by James (1995, p.227), the Federal Reserve Act was defined as "An Act to provide for the Establishment of Federal Reserve Banks ... and to afford means of rediscounting commercial paper." As for information on dollar acceptances, the editors of the Acceptance Bulletin constructed monthly series from material submitted by reporting banks. The resulting series is available January 1917 to April 1936 (the Bulletin having been discontinued at that point). From 1917 onward, the Bulletin also distinguished acceptances created to finance exports, imports, shipments and goods stored in foreign countries, domestic shipments, domestic warehouse
} 
Until World War I, the U.S. commercial paper rate was continually above the open market rate in London, sometimes by as much as 200 basis points. The creation of the Federal Reserve was followed by a sharp reduction in the differential. By 1915 the commercial paper rate was 100 basis points below the London open market rate. In 1917, when dollar acceptance rates become available, they are even lower than commercial paper rates.

Figure 1. London and New York Money Market Rates, 1900-1939

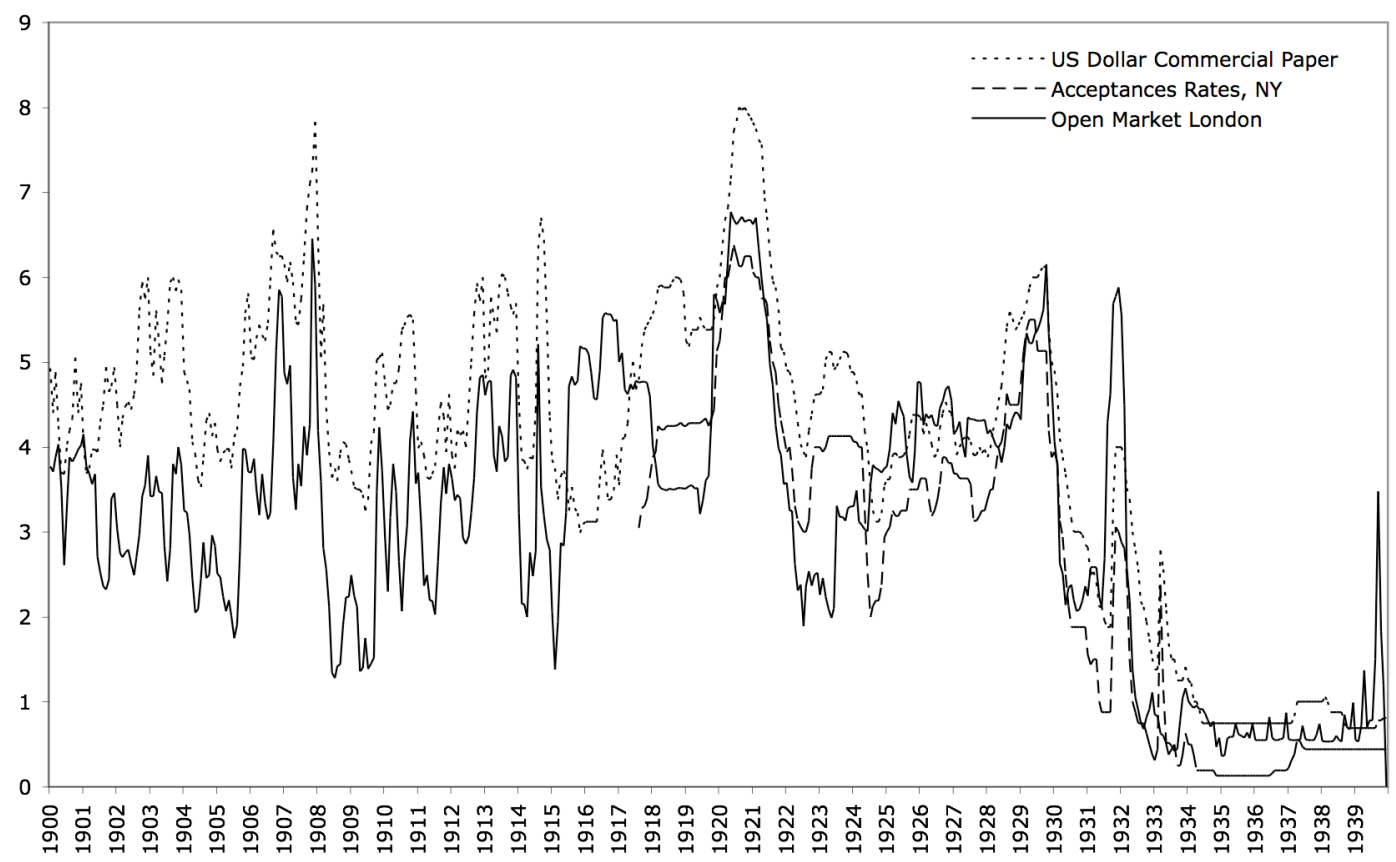

Source: see text.

The period centered on 1915 thus saw a revolution in the relative position of London and New York. Figure 2 shows that the total outstanding acceptances of U.S. banks began rising that same year. ${ }^{26}$ The Guaranty Trust Company claims to have been first to begin originating acceptances and allowing foreign correspondents to draw on it. Our data support this, showing \$18.2 million of acceptances in its December 1914 balance-sheet, a date when the market was probably not much bigger than that. ${ }^{27}$ Over the course of 1915, more banks then began entering the market. This is when the interest differential in Figure 1 reverses. These changes may have been due not to the advent of the Fed, of course, but to the dislocations of the war and limited sterling convertibility. However, whereas the latter presumably would have had only transitory effects, the shift in London-New York interest

credits and dollar exchange Federal Reserve reports and bulletins then provide information on acceptances between 1936 and 1939.

${ }^{26}$ From Federal Reserve statistics and the Acceptance Bulletin.

${ }^{27}$ It complains, however, the acceptances it originated failed to find ready buyers, forcing it to hold its own paper (Guaranty Trust 1919). 
differentials was permanent. While this is consistent with both our second and third hypotheses above, it is inconsistent with the first (emphasizing the overwhelming importance of firstmover advantage).

Figure 2 highlights the role of the Fed in nurturing the infant industry; it shows acceptances in the Fed's custody from 1915 through 1939. The Fed's Annual Report for 1915 points to this year as when the market for acceptances first showed signs of life. ${ }^{28}$ The annual report describes the Federal Reserve Bank of Boston made "every effort to further and develop that business," buying acceptances from Massachusetts banking institutions engaged in financing "hides and wool from South America and cotton and jute from the orient and other sections of the world" in the early months of 1915, trade that had previously been financed "through credits drawn on European centers.",29

Figure 2. Total Outstanding Acceptances and Amounts Held by the Federal Reserve Board (Own Account or for Account of Foreign Correspondents), in $\mathbf{\$} \mathbf{b}$.

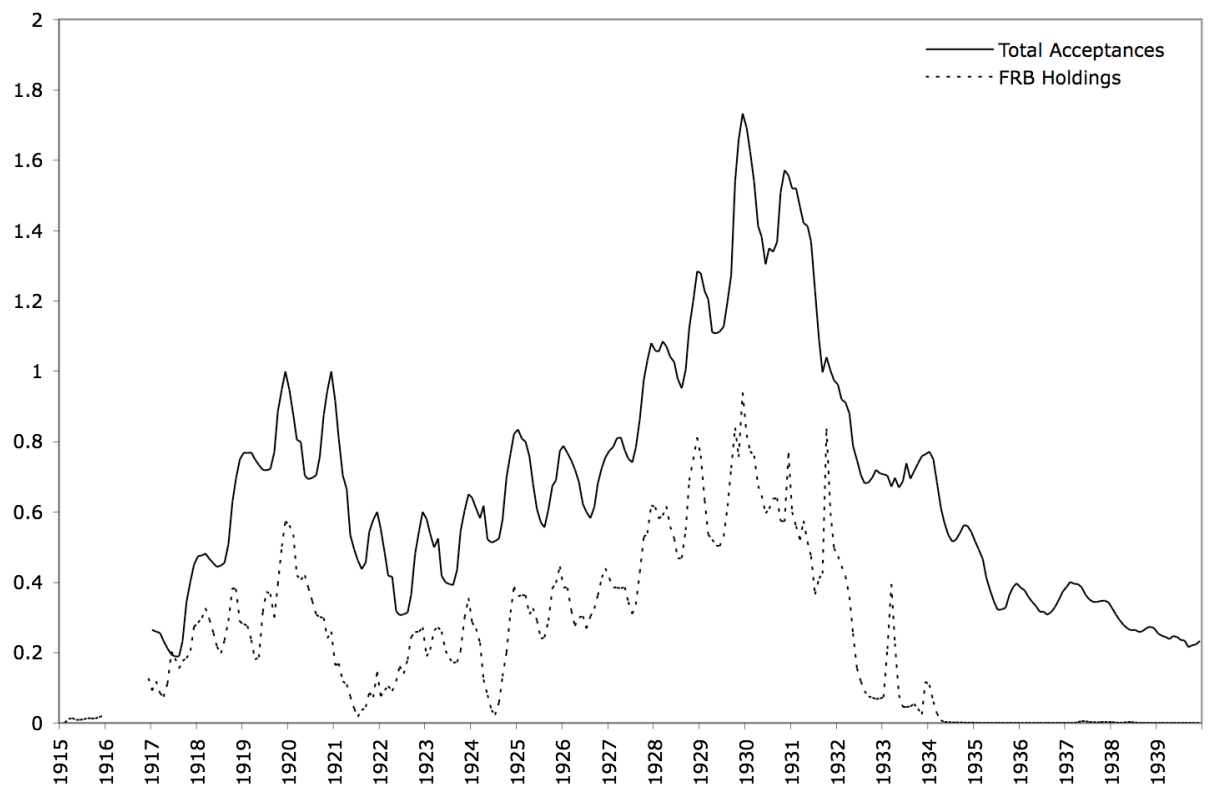

Source: See text.

Further evidence can be garnered from the minutes of the Open Market Investment Committee. ${ }^{30}$ For instance a statement pertaining to the policy adopted in the April 1923 meeting compared the alleged hands-off policy of the Bank of England (allowing the maintenance of a spread between the open market rate and the rediscount rate) and recommended a more aggressive policy for the Fed: "A Policy as drastic as that of the Bank of England, for instance, which always aims to make the market pay a penalty rate upon recourse

\footnotetext{
${ }^{28}$ See the Federal Reserve Board's Annual Report for 1915.

${ }^{29}$ The report also mentions that 7 additional banks in the area had moved into the acceptance business (Federal Reserve System, Annual Report for 1915, p. 136).

30. A body created in 1923 to monitor Fed's investment and money market policy and operations.
} 
to the bank, is not always suited to the American bill market, and if applied might have an adverse effect upon the establishment of dollar credit and dollar bills in overseas trade and world markets, and it seems reasonably certain that the sterling credit would quickly drive the dollar credit from those markets. It is probable therefore that we must continue for some time a somewhat paternalistic attitude towards the market for dollar bills in this country". 31 Other passages point in the same direction. Together they suggest that during the 1910s and 1920s, the Fed made a sustained effort to render dollar acceptances more attractive relative to their sterling competitors.

We see in Figure 2 that the market in acceptances experienced two boom-and-bust cycles. There was a sharp increase toward the end of World War I, coincident with the increase in U.S. trade associated with direct American military involvement. The peak reached in 191920 was then followed by a sharp decline. The second expansion started in 1922-3 and peaked after the stock market and the economy in 1929. The subsequent decline in the volume of acceptances persisted through the 1930s.

\section{Figure 3. Share of the Fed in the Acceptance Market and Relative Interest Rates}

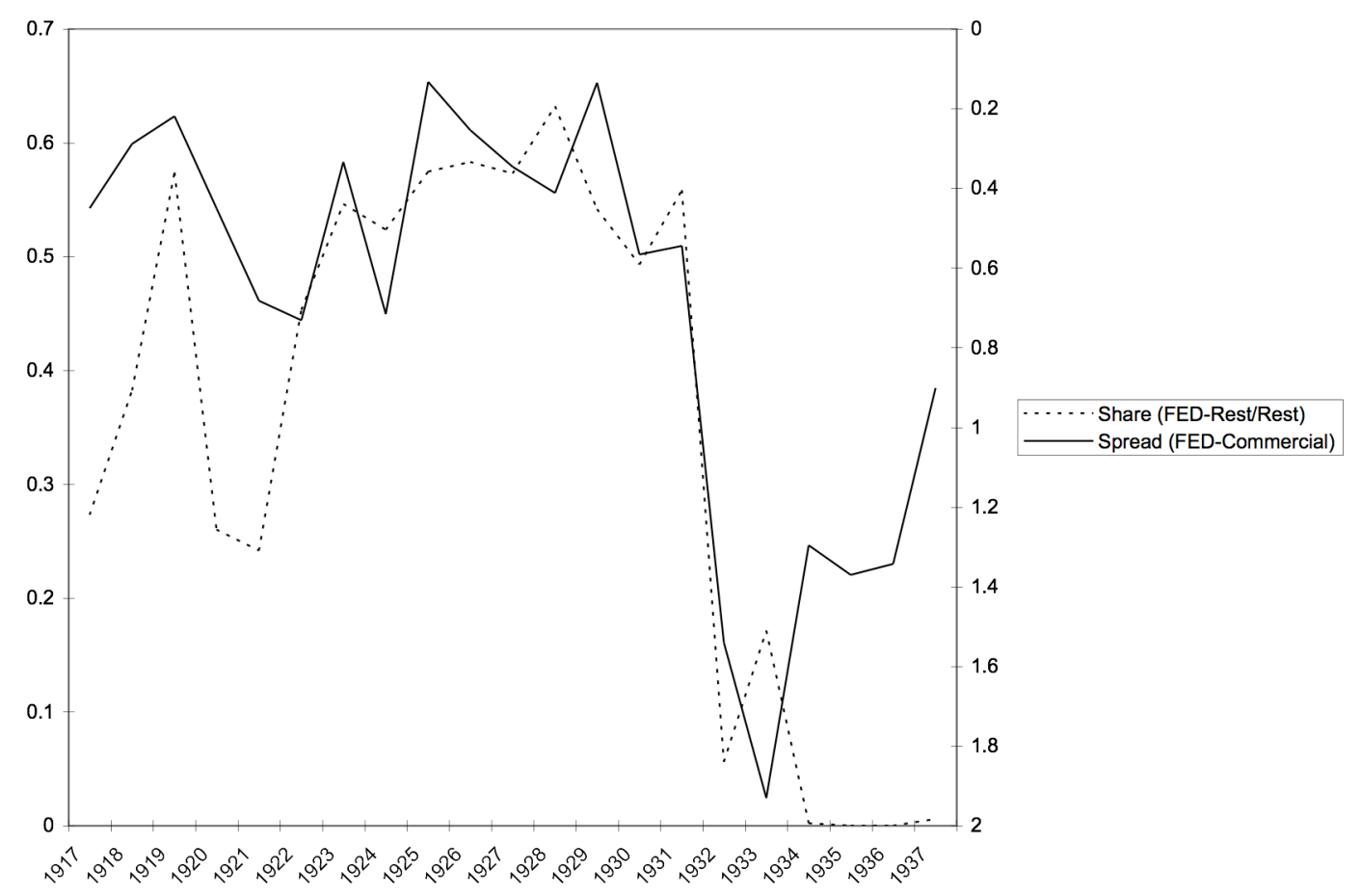

Source: Authors' computations from sources in text.

Looking at total acceptances in conjunction with Fed holdings directs one's attention to periods like 1917 when the central bank was evidently the only purchaser on the secondary

31. Federal Reserve Archival System for Economic Research, Federal Reserve Open Market Investment Committee (Open Market Policy Conference), Excerpts, 1923 to 1928. Quote taken from "Excerpts of the Federal Open Market Investment Committee during 1923”, p. 5. 
market. ${ }^{32}$ On average the Fed held between a quarter and two-thirds of outstanding acceptances. ${ }^{33}$ Suggestively, the withdrawal of the Fed from the market coincides with the decline of the industry in the early 1930 s.

Figure 3 juxtaposes two indicators of official support for the market. The first is the Fed's holdings as a share of outstanding acceptances. The second is the spread between the Federal Reserve and market rates for acceptances. The narrower the spread, the stronger the support (a lower spread suggesting that the Fed was more anxious to step into the market). With the notable exception of the wake of the two trade busts (1921 and 1931), the Fed kept its rate close the market rate and purchased a substantial fraction of acceptances outstanding. Again, this is consistent with the view that the U.S. central bank played an active and, indeed, critical role in fostering the new market in dollar-denominated trade credit.

\section{The Empire Strikes Back}

We turn next to conditions on the London market. Figure 4 shows the correlation between Bank rate (the Bank of England's rediscount rate) and the open market discount rate before and after 1914 (analogous to Figure 3 for the United States). The correlation loosens during and after the war, suggesting that the Bank of England, grappling with a weak sterling exchange rate, could not support the market as freely (it faced a trade-off between market support and protection of its gold reserves). ${ }^{34}$

Figure 4. Bank of England Rediscount Rate and Open Market Rate 1900-1939

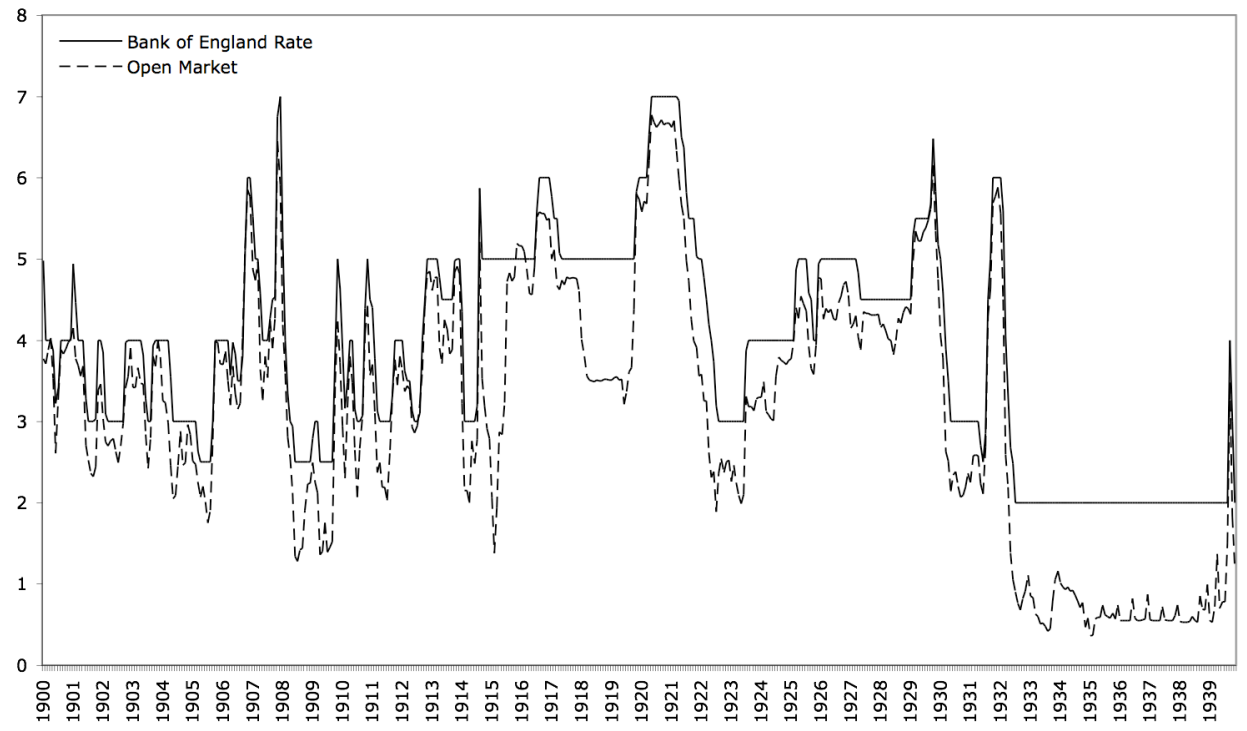

Source: NBER Historical Macro Database.

\footnotetext{
${ }^{32}$ Holdings are measured here as total holdings, i.e. holdings for its own account and for the account of foreign customers, mostly central banks.

${ }^{33}$ Again, either on its own account or on that of foreign central banks holding deposits with it.

${ }^{34}$ See Sayers (1967) for a discussion of the conflicts created by the multiplicity of policy objectives during the 1920 s and the partial remedies found to deal with it.
} 
Notwithstanding those difficulties, the Bank of England and the British government made a determined effort not just to maintain London's position but to expand its reach. ${ }^{35}$ The war created an opportunity to address the challenge from German banks and the potential challenge from the United States.

In 1916, a blueprint for a post-war UK-centered international economic system was described at the Paris Economic Conference. Market access and shipping privileges would be used to reward allies and punish enemies and neutrals - meaning Germany and the United States, respectively. Reliance on the Empire, together with selective Continental alliances, would provide the critical mass for a London-centered European commercial and financial system. $^{36}$

International, overseas and merchant banks were encouraged to expand their geographical reach and received active official support. The British government seized the London branch of the Anglo-Austrian Bank, a leading Vienna based institution with links to Germany. Once the government and its friends in the private sector acquired its records and correspondence, they could see how its affiliated institutions operated in Central Europe. This knowledge "eased the way for private British interests to seize control of the Anglo-Austrian network." ${ }^{37}$ After the war, such expropriations were justified under Article 248 of the Versailles Treaty permitting the organization, in 1922, under the aegis of the Bank of England of the "new" Anglo-Austrian Bank, which in turn controlled the new Anglo-Czech Bank, formed to take over the branches of the former Anglo-Austrian bank in Czechoslovakia. Similar policies were adopted for Turkey, where German banks had had a prominent role before World War I and which like the Habsburg Empire had been an ally of Germany.

To what extent did these policies extend sterling's reach? Consider Latin America, a region where Britain's financial leadership was actively disputed by the United States. Before World War I, the role of the mark in financing Latin trade had expanded on the basis of growing German industrial exports. Integral to this process were German overseas banks: the Banco Aleman Transatlantico, the Deutsch-Sudamerikanische Bank, Brazilianische Bank für Deutschland, and the Bank für Chile un Deutschland, which were active primarily in Argentina, Brazil and Chile. ${ }^{38}$ Most were controlled by or affiliated with the "great banks" that were the pillars of the German banking system. ${ }^{39}$

With the outbreak of the war, the British authorities sought to limit Germany's capacity to trade and the German banks' ability to extend trade finance. The Latin and London branches of German overseas banks were shut down or expropriated. ${ }^{40}$ Utilizing information obtained

\footnotetext{
35 See Robinson (1923), Baster (1935) and Jones (1995).

${ }^{36}$ Parrini argues that U.S. declaration of war and Wilson's sponsoring of the League of Nation were direct responses to this challenge. They led Britain to revise earlier plans and offer the U.S. "co-chairmanship" of the global trading and financial system (Parrini 1967).

${ }^{37}$ Parrini (1967), p.129.

${ }^{38}$ See Battilossi (2006) and Briones and Villela (2006).

${ }^{39}$ The Deutsche Bank, the Discontogesellschaft, or the Dresdner Bank. Such arrangements were not specific to Latin America. The Deutsche-Asiatische Bank for instance was active in China.

${ }^{40}$ In 1914, the Allies forced the Deutsch-Asiatische Bank Branches in China to shut down. These branches were barely able to resume their operation in 1918. See King (1989) and Horesh (2008).
} 
through these expropriations, British merchant and overseas banks moved to fill the void. Table 1 shows data for 1913 and 1921 assembled from the Bankers' Almanac. We compare Germany's four Latin American banks with three British rivals. As can be seen, German overseas banks lost their parent connections in London and were replaced by British merchant banks. The merchant houses that moved, Kleinworts, Shroders, and Seligmans, were wellestablished London institutions and active in the sterling area. ${ }^{41}$ Where the capital and balance sheets of British and German banks operating in Latin America had been comparable in 1913, British banks were much larger in $1921 .{ }^{42}$ We take this as indicating that accounts suggesting that the war was good for the U.S. but bad for Britain lack balance. The use of political means to eliminate German competition could and in some cases did reinforce the position of London. $^{43}$

What was the net effect on the sterling and dollar acceptance markets? Figure 5 shows their evolution. ${ }^{44}$ We use here the most comprehensive definition of sterling acceptances, meaning both those drawn abroad and those drawn domestically, and the corresponding U.S. totals. $^{45}$ The value of dollar and sterling acceptances was quite close in the late 1920s. This figure for private international claims resembles to a striking degree the findings of Eichengreen and Flandreau (2009) for official international reserve holdings. ${ }^{46}$

Again as with official reserves, the dollar's share then shrank in the economic crisis of the 1930s. Where the nominal value of sterling acceptances fell by half between the peak in 1929 and the middle of the 1930s, dollar acceptances in 1935 were barely a seventh what they had been in 1929. Again, this parallels what we have found for changes in the composition of international reserve holdings between the 1930s and 1930s. In the case of acceptances (as in the case of reserves), the fact that the U.S. depression was more severe and that U.S. trade contracted more rapidly than British trade is part of the story, but only a part. We return to this.

The picture that emerges from this section is one of competition between two international currencies, not the dominance of one. Reinforcing the point, Figure 6 compares

\footnotetext{
41 .Andof German origin and with a strong German information base

${ }^{42}$ Inflation played a role in the reduction in the capital base but geopolitical dislocations were decisive. Had shareholders of German overseas banks felt that recapitalization would bring revenues they would have supplied the needed resources.

${ }^{43} \mathrm{We}$ also find the grabbing hand where did not expect it. with the UK and U.S. stripping Germany from its banking system and taking advantage of the war to expand dramatically.

${ }^{44}$ There is no British equivalent of the Acceptance Bulletin (no central body collected relevant information). The figures we report are for the sub-period 1927-1937. Truptil (1936, p. $159 \mathrm{ff}$ ) used material from the Committee on Finance and Industry (1931) together with assumptions about stability of various types of banks' proportions in totals to impute missing information. Baster (1937) then extended Truptil's estimates. We have also drawn on unpublished estimates by the Bank of England. Starting in the 1930s the Bank provided estimates of the volume of acceptances (Bank of England Archive EID4/86). We thank Olivier Accominotti for this material.

${ }^{45}$ This seems to be the best way to go: because domestic trade could also be financed by domestic drafts, trying to disentangle domestic and foreign drafts is hopeless. Statisticians of British acceptances typically attempt to identify acceptances from banks' balances-sheets, as the publishers of the Acceptance Bulletin did for the United States.

${ }^{46}$. This is only half surprising of course since central bank foreign exchange reserves mostly comprised bills (or acceptances), deposits and government bonds. In the Fed's case foreign deposits were reinvested on acceptaces, thus establishing a direct link between demand and supply.
} 
the market-bank spreads for London and New York. After 1922, spreads in the two markets are comparable. Insofar as the spread between official and market rates is indicative of central bank support, Figure 6 is telling us that central banks and currencies competed with one another.

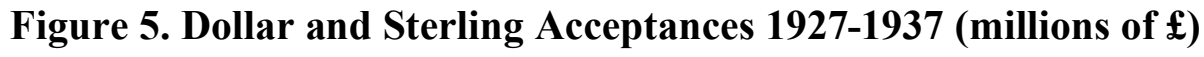

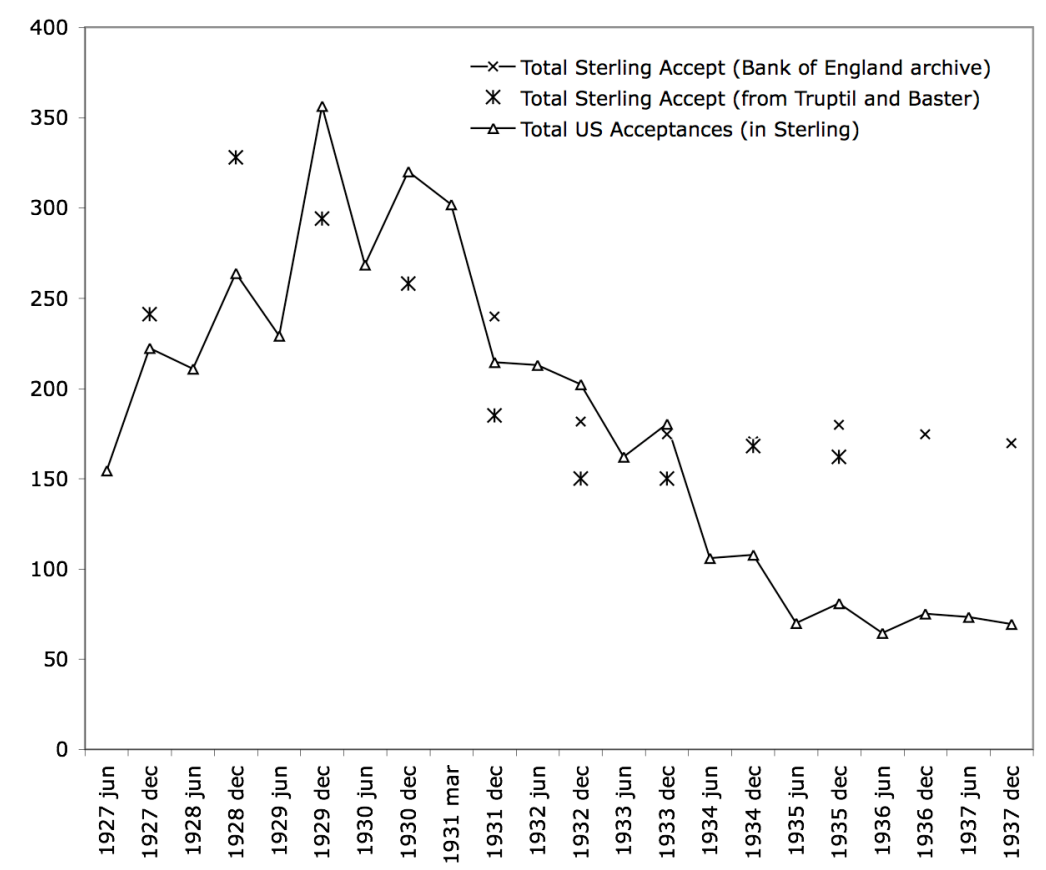

Source: Authors' estimates based on documents described in the text.

The 1930s then saw both central banks walk away from the market, the Fed even more so than the Bank of England. There is a striking correlation with Figure 5, which shows total U.S. acceptances declining much more dramatically than total British acceptances.

\section{The Supply of Acceptances: Evidence from Panel Data}

In this section we look more closely at the growth of the dollar acceptance market in the 1920s. A first interpretation of this phenomenon is as market led. U.S. banks were capable of entering the market; they only had to be freed of regulatory restrictions. A second interpretation is that the transition was government led. It would not have occurred had the Fed not substituted for the missing secondary market.

One can identify two variants of the market-led hypothesis. One emphasizes branching. Overseas branches were needed to gather information on foreign markets of the sort that the London banks had traditionally. They were needed in order to be able to conveniently attract the business of merchants who did not reside in the United States. This is the dominant view in much previous historical research as well as contemporary policy debate. Exporters, in 
particular, insisted on a US system of branch that would handle US trade and US trade secrets. ${ }^{47}$

\section{Figure 6. Spreads between Official and Market Rates in London and New York 1917-1939}

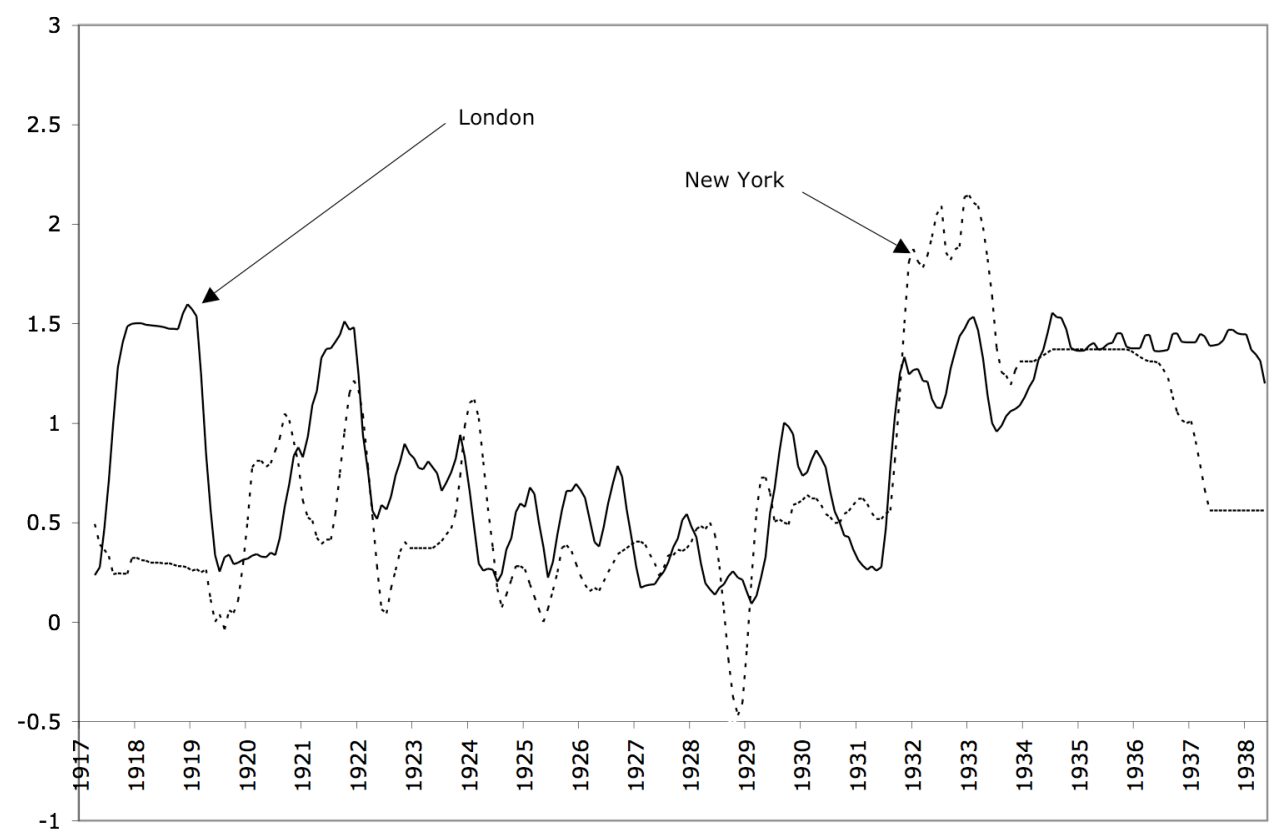

Source: Source: NBER Historical Macro Database.

The other variant is that U.S. banks, once liberated from restrictions on dealing in trade credit, could build on their existing connections with importers and exporters. It was foreign trade and not foreign branches on which the new acceptance business rested. Previous scholars have paid less attention to this hypothesis, but Figure 7 (which compares annual US trade -imports plus exports -- with the total amount of acceptances originated annually) is at least not inconsistent with it.

Who did branch and when? Table 2 summarizes the extent of branching. ${ }^{48}$ The number of banks that developed networks of foreign branches, either directly or through subsidiaries,

\footnotetext{
${ }^{47}$ See Phelps (1927), Lewis (1938), Parrini (1969), Cleveland and Huertas (1985), Stallings (1987) and more recently, Cattani and Tschoegl (2002).

${ }^{48}$ On the surface previous estimates differ, although on closer inspection discrepancies can be explained away. This we did by constructing our own estimates from the Bankers' Almanac. Phelps provides a table with number branches by bank at some benchmark years $(1913,1920,1926)$ and another one with banks by region in 1926 (Phelps (1927), 211\& 212). Lewis (1938) expands Phelps' table for branching to 1919, 1924, 1929, 1933, and 1935. Parrini (1969, p.116) offers a decomposition of branching in 1920 by country and banking "family" (the National City-International Banking Corporation conglomerate vs. the Morgan affiliates. Cleveland and Huertas (1985, pp.324-5 provide a table describing National City Bank/Citigroup per region. Finally Stallings (1987 p.70) tracks U.S. branches in Latin America between 1914 and 1930. The Bankers Almanac gives for each city a list of
} 
was limited. National City Bank, First National Bank of Boston, Guaranty Trust, and Chase dominate the list. Other institutions boasted "representative offices," but these representatives (sometimes single individuals) in other countries were not branches proper. This is not inconsistent with industrialists complains (Parrini 1969) that banks were not doing enough.

Figure 7. U.S. Trade (Imports plus Exports) and Total Acceptances Originated Annually (millions USD)

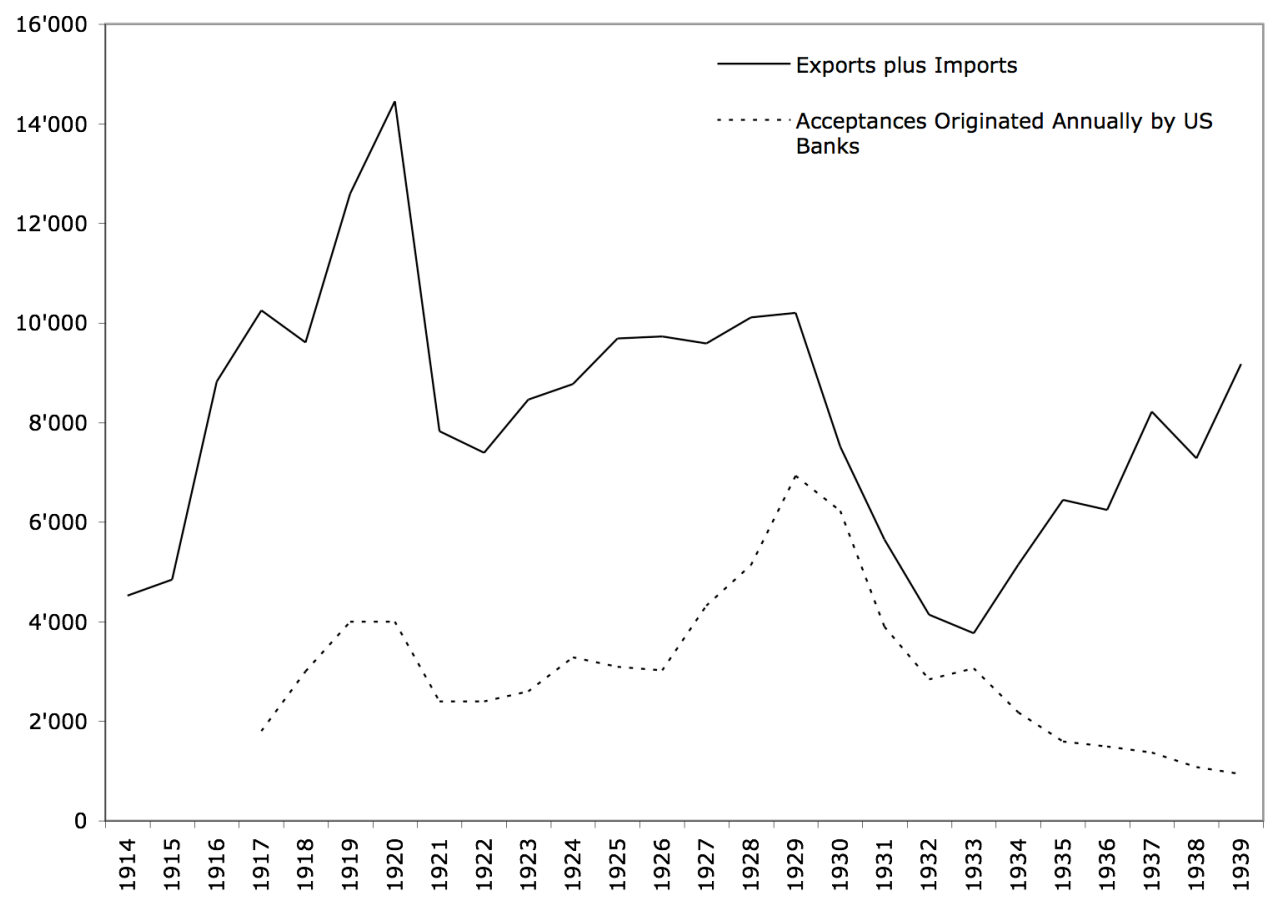

Source: See text. Total acceptances originated annually are obtained by assuming typical acceptances have 3 months maturity.

Table 3 shows the value of acceptances originated by bank. ${ }^{49}$ While banks with foreign branches usually ranked at the top, it appears that the acceptance market was quite competitive. Data published by Kniffin (1920) for May 1, 1917 enables us to compute a HerfindhalHirschman acceptance market concentration index. We find 0.47 a low figure that is consistent with the null hypothesis of a competitive market. Using league tables in the Acceptance Bulletin and data from bank's balance sheets, we find that the top four banks accounted for 30 per cent of the market at the end of 1927, a substantial but not overwhelming fraction; to get 85 per cent, one must consider 40 banks. ${ }^{50}$ Given the fact that a fair number of banks with few or no foreign branches appear to have been active in the market, one can question the conventional view that branching was key. The alternative interpretation would be that in order to increase acceptances one only needed good correspondents abroad, competitive

institutions in operation. This being a British source, it may however have undercounted U.S. banks.. Where Phelps and Lewis list 57 National City Company branches in 1920 when Cleveland and Huertas have 81. As shown in the table, Cleveland and Huertas must be considering all the branches of the National City complex. ${ }^{49}$ This is assembled from the Acceptance Bulletin's league tables for the value of acceptances originated.

50 Acceptance Bulletin (January 1928), pp. 3-4. 
discount rates, reasonable transaction costs making the drawing of drafts on New York attractive, and ready access to a sufficiently large clientele.

We now analyze these factors more systematically. Each bank, we assume, originates acceptances in proportion to capital and reserves (to which acceptances were tied through regulation or balance-sheet). ${ }^{51}$ The bank's acceptance business was also influenced by the total size of the market (the demand for trade credit), as captured by the value of acceptances or total U.S. trade (imports plus exports). Finally, we ask if branches matter.

Data come from balance sheets for the period 1915-1939 for 20 banks. $^{52}$ In the illustrative example below (Figure 8), the exact same figure for acceptances $(\$ 6,482,165.82)$ appears both on the asset side (they are claims on customers) and on the liability side (the bank has committed itself to pay the amount at maturity). ${ }^{53}$ Balance sheets were also used to gather figures for other bank attributes (capital, reserves, total assets etc.). U.S. trade is from the NBER database, total acceptances from the Acceptance Bulletin and Federal Reserve's Banking and Monetary Statistics. All variables are in logs.

\section{Figure 8. Looking for Acceptance Data in Banks Balance Sheets}

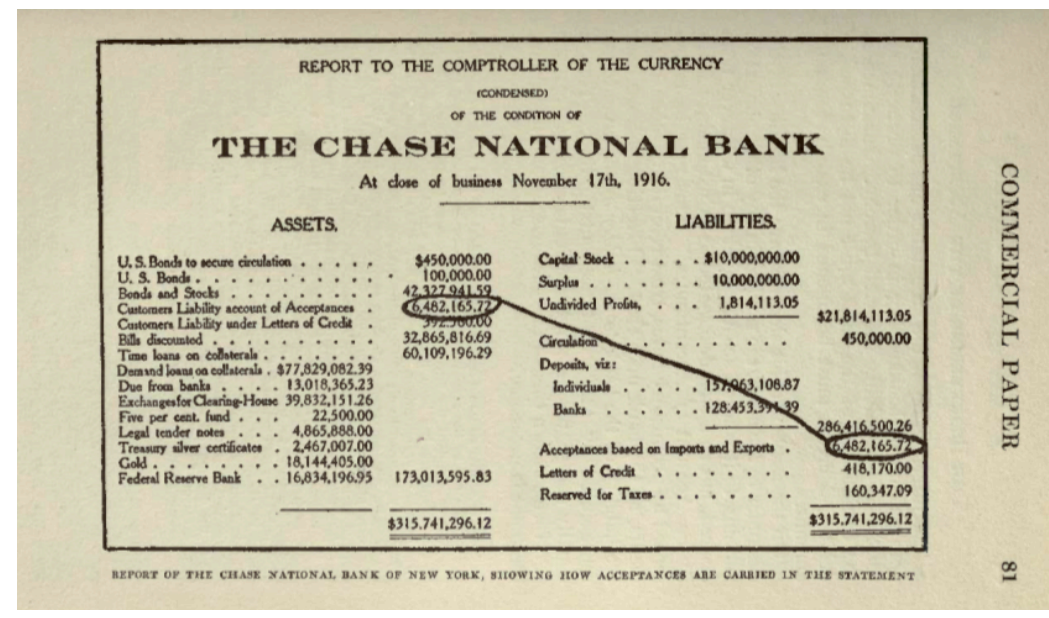

Source: Kniffin 1920, p. 81.

We use a simple dummy variable for branches. While some banks branched more heavily than others, it is hard to know how to weigh a single branch in Paris against several branches in Cuba. Reassuringly, results were not affected by alternative specifications. ${ }^{54}$

\footnotetext{
${ }^{51}$ The Federal Reserve Act authorized national banks to purchase or discount acceptances up to 50 per cent of capital. The ceiling was raised to 100 per cent subsequently.

52 They come from the Baker Library at Harvard, Columbia's Online Digital Collection, the British Library and the Graduate Institute collection of banks balance-sheets. See appendix.

53 Real- life situations tend to be more complex. Occasionally, acceptances on the liability side are mixed with related securities like credit lines. It was generally possible to get fairly reliable numbers, which were checked against the rankings in The Acceptance Bulletin's league tables.

${ }^{54} \mathrm{We}$ abstract from reverse causation. It could be, of course, that branching does not add more acceptances, but that banks that did a number of things had more acceptances and had then to branch in order to meet customers'
} 
The panel is unbalanced owing to missing observations (some banks were merged, others were closed). We provide two sets of panel estimates, with and without clustered the standard errors. The latter may are more appropriate, since we are combining bank-level and macroeconomic variables (Moulton 1990).

Tables 4 shows the results. Bank size, whether measured by total assets or capital, is generally significant and has a positive effect. ${ }^{55}$ The macro variables - total acceptances and total trade - are significant and positive. ${ }^{56}$ Finally branching is in general significant. The existence of branches is associated with a 60 (upper bound estimate) per cent increase in outstanding acceptances.

But magnitudes matter: what do the estimates imply for the role of branching in the growth of the market? Recall that the top four banks controlled about 30 per cent of the total market for acceptances in 1928. Our estimates imply that, had not been for their branches, they would have had only 20 per cent of the market, a noticeable but not ruinous decline. The conclusion, therefore, is that branches helped but were not indispensible to the growth of the acceptance market. Banks that did not go overseas were still able to enter the market, making use of their established connections with U.S. importers and exporters.

Tables 5 and 6 assess the contribution of the Fed. Table 5 considers a narrow definition of Fed's support: total acceptances held on the Fed's own account. This variable tends to be statistically significant at conventional confidence levels even when it is included together with total acceptances outstanding and U.S. trade, with which it is collinear. ${ }^{57}$ The point estimates move around (as a function of which control variables are included), but they uniformly suggest that Fed purchases were as important as the aggregate growth of the market for individual bank behavior. Knowing that it might be possible to lay off acceptances on the Fed caused individual banks to respond roughly twice as fast to market growth as otherwise. This makes sense: acceptances brought revenue while immobilizing close to zero capital. Banks thus were prepared to issue as many as they would be sure to sell (subject to regulatory constraints that tied acceptances to capital and reserves). If by contrast there were less buyers and banks faced the risk of having to buy their own paper, the cost of underwriting more acceptances rose, rendering banks more reluctant to originate them.

The narrow definition of support may not be the best one. The Fed also received deposits from foreign central banks (prominently from the Bank of France) which it then parked as acceptances, again in part to foster the growth of the market. While the Fed did not determine the amounts deposited, it certainly decided what it would do with it - that it would recycle them as acceptances as opposed to other investments (it may have invested in treasuries, for instance). In Table 6 we therefore add these acceptances held by the Fed for the account of others to acceptances purchased for its own account. The official-purchases variable is now even more significant than before, reinforcing the conclusion that they played an important-market making role.

needs. However, considering this would weaken the case for branches, and given our later finding, this is not essential for us as it would only strengthen our conclusions.

${ }_{55}^{55}$ Introducing capital and total assets together creates a problem of multicollinearity, as one would expect.

${ }_{57}^{56}$ Although, again, multicollinearity is an issue.

${ }^{57}$ In this table and the one that follows we continue to cluster the standard errors. 
The results from Tables 5 and 6 suggest that, to the extent that the Federal Reserve helped the market through active purchases during the 1920s, it must by definition have penalized it when it withdrew in the 1930s. Evidently, the failure of the Fed to support the market after 1931 was an important factor in its absolute and relative decline. Reasons for this failure should be the topic of future research. A contemporary line, echoed in a recent monograph by Mehrling (2010), is that in driving up the price and driving down the return on acceptances the Fed made them less attractive for private investors to hold. Banks in particular were encouraged to invest instead in more rewarding over the counter securities-repurchase agreements and loans to stock brokers. When crisis hit, the Fed then found itself having to choose between defending the dollar's gold parity and providing support to the banks, which were heavily invested in government securities on the one hand, and continuing to support the nascent market in acceptances on the other. Forced to choose, it opted to sacrifice the acceptances "infant industry," which at that time had barely evolved beyond the juvenile stage.

We undertook a number of robustness checks of these results. In Table 7 we substitute an alternative measure of Fed support for the market, namely the spread between the official and commercial discount rates on acceptances. The results are as before; these strongly support the notion that official support mattered. In Table 8 we address the concern that Fed investments in acceptances and total investments in acceptances are simultaneously determined by redefining the dependent variable as the market share of an individual bank in an individual year. The results are again consistent with what we found before, except that the effect of branching is now somewhat larger. The second panel of the table, where we include the Fed's share as an explanatory variable, suggests that official support for the market favored the big players disproportionately (big banks dominating our sample).

\section{Conclusion}

This paper has offered new evidence on the rise of the dollar as an international currency during World War I and the interwar years. As a heuristic we have used the analogy between international currencies and network effects in the adoption of technologies. The question is whether the international monetary and financial system was subject to strong lock-in and irreversibility, whether it could in fact be shifted from one equilibrium to another by large shocks and the actions of large players like central banks, or whether there were in fact limits on increasing returns and network externalities, permitting several monetary technologies to coexist.

Much previous literature emphasizes the first hypothesis, and a good deal favors the second. It is argued that sterling remained the dominant current in private as well as official international transactions until after World War II, long after the United States surpassed Britain as the largest economy and leading trading nation. It is said that this lag between shifts in economic and monetary circumstances reflected the strength of increasing returns, network externalities, and London's first-mover advantage. When the shift finally occurred, it reflected the shock of the war and the support provided by the Fed. To the extent that market forces played a role, they were mediated by the foreign branching of U.S. banks.

In this paper we have challenged this conventional wisdom. We show that the shift occurred already much earlier, during and after World War I. Already in the 1920s the dollar rivaled and, indeed, surpassed sterling as a source of trade credit. This finding parallels what 
we found previously for the official use of international currencies, that is, for the composition of central bank reserves.

We show next that it was not merely the growth of foreign branches but also the growth of U.S. trade that allowed American banks to enter the market. Increased trade fostered the growth of a network of correspondents abroad that enabled American banks to enter the acceptance market as soon as they were endowed with competitive discount rates and freed from regulatory restrictions.

We show third that not just market forces (the actions of American commercial banks and trust companies) but also public support - the Fed's role as architect - played a role in the dollar's rapid catch up and brief overtaking of sterling as the leading international currency. This occurred before a liquid secondary market of private and institutional investors to which the acceptances originated by U.S. banks and trust companies could be resold was built. ${ }^{58}$ The mechanism that enabled to skip this stage was the Fed, which stepped in as secondary-marketmaker of last resort. Our estimates suggest that the U.S. market in trade acceptances grew significantly faster than it would have in the absence of this official support. There is a message here for governments like China's seeking to promote international use of its currency. 59

We show fourth that when central banks stepped out of the market for acceptances in the 1930s, the market in dollar acceptances collapsed all but completely, whereas the market in sterling acceptances did not. Evidently the task of building a new secondary market of individual and institutional investors, analogous to what London had already done in the $19^{\text {th }}$ century, was more difficult than supposed. Indeed, the Fed's aggressive intervention as buyer of last resort may have stifled rather than fostering the development of that market.

We show finally that the image of strongly increasing returns and pervasive network externalities leaving room for only one monetary technology is misleading. There were limits to these network effects. There was room for both sterling and the dollar and for both London and New York all through the 1920s. This suggests that there will be room for more than one international currency in the $21^{\text {st }}$ century. It is not a winner-take-all game.

\footnotetext{
${ }^{58}$ As explained by the industry's advocate, the American Acceptance Council, the investor "would have to be educated, first as to the nature of a bankers' acceptance, second as to its attractiveness as an investment, and third, owing to its quality as a doubly secured risk [that it was guaranteed both by the original issuer and the accepting bank], that it would be offered at a lower rate than he had been accustomed to, when buying the best single name commercial paper." American Acceptance Council (1931), p.17.

${ }^{59}$ China has already begun moving in this direction by encouraging limited use of the renminbi for trade settlements. It is negotiating arrangements with Brazil whereby the two countries can use their own currency in bilateral transactions. It has allowed select banks to issue renminbi-denominated bonds in Hong Kong and done a sovereign bond issue in renminbi there itself. It has allowed the multilaterals to issue renminbi-denominated securities in Shanghai.
} 
Table 1. German and British Overseas Banks in Latin America 1913 vs. 1921

(in $£$ million 1913)

\begin{tabular}{|c|c|c|c|c|c|c|}
\hline & \multicolumn{2}{|c|}{ MAIN LONDON AGENT } & \multicolumn{2}{|c|}{ TOTAL ASSETS } & \multicolumn{2}{|c|}{ CAPITAL } \\
\hline & 1913 & 1921 & 1913 & 1921 & 1913 & 1921 \\
\hline \multicolumn{7}{|c|}{ German Foreign Banks in Latin America } \\
\hline Banco Aleman Transat. & Deutsche Bk & Kleinwort & 14.0 & 7.0 & 2.0 & 0.1 \\
\hline Deutsch-Sudam. Bk. & Dresdner Bk & Kleinw, Shröd., Japhet & 7.0 & 1.9 & 1.0 & 0.1 \\
\hline Bk. für Chile und Deutsch. & Disconto (a) & None (b) & 3.0 & 0.2 & 0.2 & 0.0 \\
\hline Brazilian. Bk für Deutsch. & Disconto (a) & None (b) & 7.0 & 0.8 & 0.5 & 0.1 \\
\hline TOTAL & & & 30.9 & 10 & 3.5 & 0.4 \\
\hline \multicolumn{7}{|c|}{ Main British Overseas Banks in Latin America } \\
\hline Anglo-South American & own & own & 14.0 & 57.6 & 1.3 & 3.5 \\
\hline London and River Plate & own & own & 35.0 & 41.7 & 1.2 & 1.4 \\
\hline London and Brazilian Bank & own & own & 20.0 & 25.7 & 1.0 & 1.0 \\
\hline TOTAL & & & 69.0 & 125.0 & 3.5 & 5.9 \\
\hline
\end{tabular}

Source: Authors, from Bankers' Almanac. Conversions in 1913 sterling made using price indices from B. R. Mitchell's European Historical Statistics (1921 prices converted in 1913 prices) and the 1913 sterling parity of $1 £=20.4 \mathrm{M}$.

Notes: (a) short hand for Discontogesellschaft Bank; (b) the Banker's Almanac literally reported "- ". This is obviously curious in view of the fact that the whole point of the Almanac was to provide information regarding London Correspondents. 


\section{Table 2. Branching by US banks}

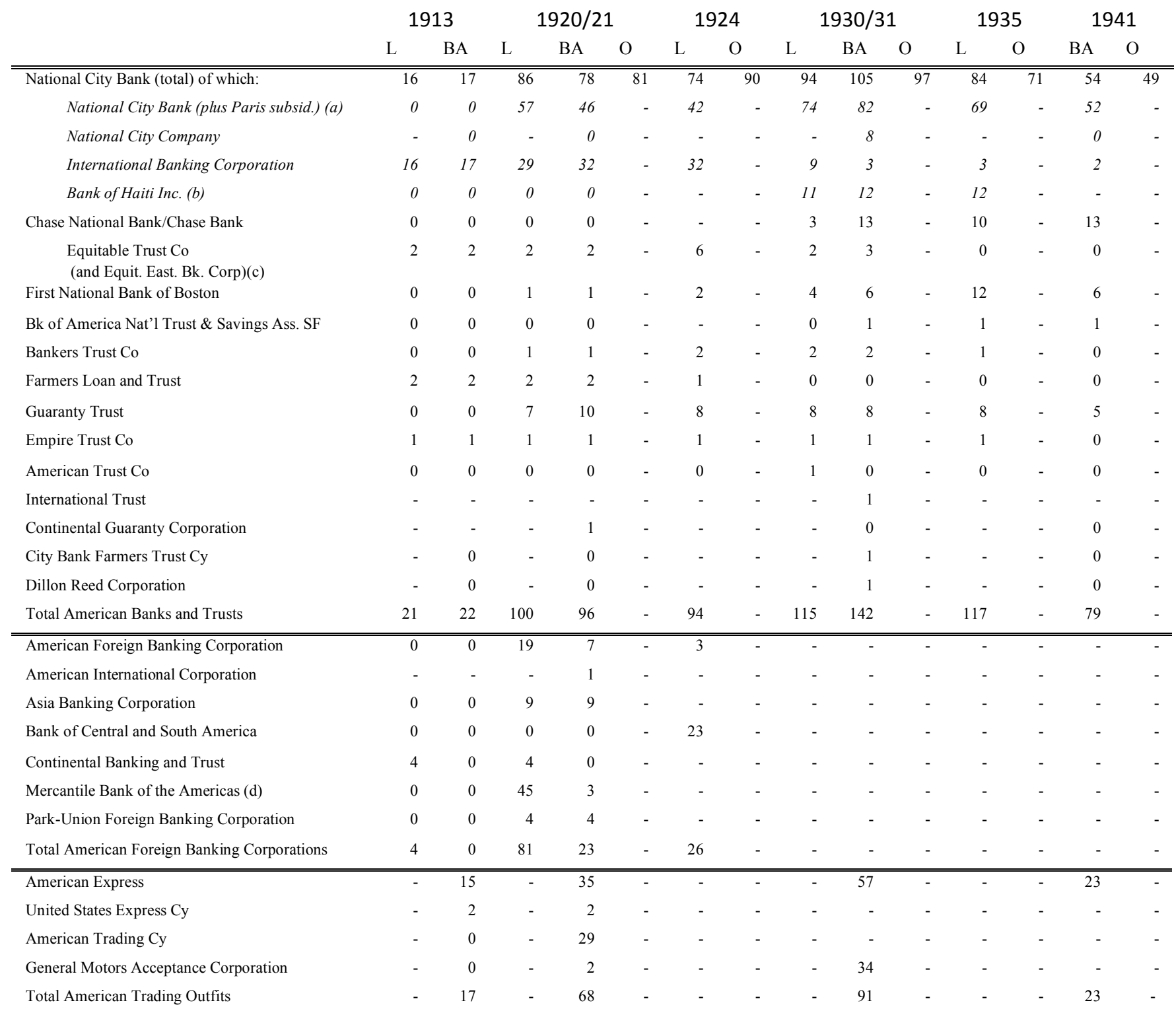

Source: BA: Authors' Own estimates; Bankers' Almanac, L: Lewis (1938), O: Other estimates for National City Bank grouping (Cleveland and Huertas (1985) and Federal Reserve Board Annual Reports). BA for 1920/21 is Bankers' Almanac, 1921-22; Lewis Figures are for 193031 corresponds to1929; BA 1930/31 is Bankers' Almanac, 1931-32.

Notes: (a) For BA 1930-31, in order to have consistency with other years, we have counted only one Cuba City branch for this date; (b) Lewis, (1938, p. 197) indicates that Bank of Haiti was sold to Haiti government in 1935. While Bank of Haiti still in BA, we thus no longer record it as a provider of branches for National City in BA 1941. (c) Equitable Eastern Banking Corporation was subsidiary of Equitable Trust. This is according to Federal Reserve Board Annual Report, 1920, p. 26. The Eastern Banking Corporation was set up in 1920. They were owned by Chase which used these as a start up for its foreign branches (d) Spread between Lewis and Bankers Almanac in 1920/21 numbers comes from Lewis including the local branches owned by the Mercantile Bank. They would be disposed of afterwards. 
Table 3. Acceptances League Table

\begin{tabular}{|c|c|c|c|c|c|c|c|c|c|c|c|c|c|c|}
\hline & Place & 1917 & 1922 & 1923 & 1927 & 1928 & 1929 & 1930 & 1931 & 1932 & 1933 & 1934 & 1935 & 1936 \\
\hline \multicolumn{15}{|c|}{ COMMERCIAL BANKS AND TRUST } \\
\hline National City & & & & & & & & & & & & & & \\
\hline National City Bk & NYC & 4 & 2 & 2 & 1 & 1 & 2 & 3 & 2 & 3 & 3 & 3 & 3 & 1 \\
\hline Farm. Loan \& Tr. & NYC & n.a. & 48 & 41 & 26 & 28 & $\mathrm{x}$ & $\mathrm{x}$ & $\mathrm{x}$ & $\mathrm{x}$ & $\mathrm{x}$ & $\mathrm{x}$ & $\mathrm{x}$ & $\mathrm{x}$ \\
\hline \multicolumn{15}{|l|}{ Chase } \\
\hline Chase National & NYC & 6 & 8 & 10 & 3 & 2 & 3 & 1 & 1 & 1 & 2 & 2 & 2 & 2 \\
\hline Nat'1 Park Bank & NYC & 8 & 29 & {$[19]$} & 31 & 22 & $\mathrm{x}$ & $\mathrm{x}$ & $\mathrm{x}$ & $\mathrm{x}$ & $\mathrm{x}$ & $\mathrm{x}$ & $\mathrm{x}$ & $\mathrm{x}$ \\
\hline Equit. Trust Cy & NYC & n.a. & 4 & 4 & 5 & 9 & 5 & $\mathrm{x}$ & $\mathrm{x}$ & $\mathrm{x}$ & $\mathrm{x}$ & $\mathrm{x}$ & $\mathrm{x}$ & $\mathrm{x}$ \\
\hline Seabord Nat'l Tr. & NYC & 60 & 30 & 15 & 14 & 19 & $\mathrm{x}$ & $\mathrm{x}$ & $\mathrm{x}$ & $\mathrm{x}$ & $\mathrm{x}$ & $\mathrm{x}$ & $\mathrm{x}$ & $\mathrm{x}$ \\
\hline \multicolumn{15}{|l|}{ Guaranty } \\
\hline Guaranty Trust & NYC & n.a. & 1 & 1 & 4 & 3 & 1 & 2 & 3 & 2 & 1 & 1 & 1 & 3 \\
\hline Nat'l Bk. of Com. & NYC & 2 & 5 & 6 & 6 & 4 & $\mathrm{x}$ & $\mathrm{x}$ & $\mathrm{x}$ & $\mathrm{x}$ & $\mathrm{x}$ & $\mathrm{x}$ & $\mathrm{x}$ & $\mathrm{x}$ \\
\hline First Nat'l Bk of B. & Bost. & 1 & 7 & 8 & 8 & 7 & 7 & 8 & 9 & 11 & 10 & 7 & 5 & 5 \\
\hline \multicolumn{15}{|l|}{ Irving Trust } \\
\hline Irving Nat'l Bk (a) & NYC & 13 & 6 & 6 & 7 & 6 & 6 & 5 & 4 & 6 & 6 & 5 & 7 & 7 \\
\hline Ameri. Exch Nat'1 & NYC & 7 & 21 & 25 & $\mathrm{x}$ & $\mathrm{x}$ & $\mathrm{x}$ & $\mathrm{x}$ & $\mathrm{x}$ & $\mathrm{x}$ & $\mathrm{x}$ & $\mathrm{x}$ & $\mathrm{x}$ & $\mathrm{x}$ \\
\hline National Shawmut & Bost. & 5 & 9 & 13 & 11 & 12 & 15 & 17 & 16 & 14 & 16 & 15 & 14 & 12 \\
\hline Bankers' Trust & NYC & - & 12 & 12 & 13 & 14 & 13 & 15 & 5 & 5 & 5 & 6 & 21 & 18 \\
\hline Old Colony Trust & Bost. & 3 & 22 & 26 & 40 & - & {$[42]$} & - & - & - & - & - & - & - \\
\hline Mech. Metals Nat'l & NYC & 9 & 26 & 24 & - & - & - & - & - & - & - & - & - & - \\
\hline JP Morgan \& Cy & NYC & $\mathrm{x}$ & $\mathrm{x}$ & $\mathrm{x}$ & $\mathrm{x}$ & $\mathrm{x}$ & $\mathrm{x}$ & $\mathrm{x}$ & $\mathrm{x}$ & $\mathrm{x}$ & $\mathrm{x}$ & 11 & 19 & 38 \\
\hline \multicolumn{15}{|c|}{ PRIVATE BANKS } \\
\hline Brown & & & & & & & & & & & & & & \\
\hline -Brown Brothers (b) & NYC & n.a. & n.a. & n.a. & 12 & 15 & 10 & 22 & 12 & 12 & 12 & 12 & 9 & 8 \\
\hline -Harriman Bthrs & NYC & n.a. & n.a. & n.a. & - & 29 & 31 & 29 & - & - & $\mathrm{x}$ & $\mathrm{x}$ & $\mathrm{x}$ & $\mathrm{x}$ \\
\hline Kid. Peab. Ac. Corp & Bost. & $\mathrm{x}$ & n.a. & n.a. & 10 & 10 & 11 & 12 & 38 & $\mathrm{x}$ & $\mathrm{x}$ & $\mathrm{x}$ & $\mathrm{x}$ & $\mathrm{x}$ \\
\hline Shroder Bkg Corp & NYC & n.a. & n.a. & n.a. & 15 & 17 & 16 & 11 & 14 & 13 & 23 & 24 & 19 & 19 \\
\hline Goldman Sachs & NYC & n.a. & n.a. & n.a. & 16 & 16 & 17 & 23 & 30 & 26 & 33 & 31 & 29 & 34 \\
\hline Lee Higginson & Bost. & n.a. & n.a. & n.a. & 18 & 24 & 24 & 20 & 21 & 22 & 22 & $\mathrm{x}$ & $\mathrm{x}$ & $\mathrm{x}$ \\
\hline Huth \& Cy & NYC & n.a. & n.a. & n.a. & 22 & 26 & 28 & 31 & 35 & 38 & 51 & 44 & 38 & 35 \\
\hline Lazard & NYC & n.a. & n.a. & n.a. & - & - & - & - & 39 & 33 & 42 & - & - & - \\
\hline Heidelbach, Ickel. & NYC & n.a. & n.a. & n.a. & 33 & - & {$[40]$} & - & - & 54 & 45 & 53 & 55 & 56 \\
\hline \multicolumn{15}{|c|}{ US FOREIGN BANKS INTERNATIONAL PARTNERSHIPS } \\
\hline Warburg & & & & & & & & & & & & & & \\
\hline$-\mathrm{IAB}$ & NYC & $\mathrm{x}$ & 3 & 3 & 2 & 5 & 4 & 4 & 6 & $\mathrm{x}$ & $\mathrm{x}$ & $\mathrm{x}$ & $\mathrm{x}$ & $\mathrm{x}$ \\
\hline -Bk of Manh. Cy (c) & NYC & - & - & - & 19 & 13 & 18 & - & - & 4 & 4 & 4 & 6 & 6 \\
\hline Fr. Am. Bkg Corp. & NYC & $\mathrm{x}$ & 24 & 25 & 24 & 25 & 21 & 19 & 27 & 20 & 13 & 16 & 16 & 16 \\
\hline Bque Belge P. l'Etr. & NYC & - & - & - & - & - & - & - & 40 & 28 & 31 & 32 & 31 & 32 \\
\hline B. Com. Ital. & NYC & - & - & - & 36 & 36 & 33 & 38 & - & 47 & 41 & 85 & 49 & 38 \\
\hline Royal Bk of Canada & NYC & - & - & - & 21 & 17 & 23 & 26 & 29 & 18 & 20 & 19 & 18 & 11 \\
\hline Asia Bkg Corp. & NYC & n.a. & 28 & 29 & $\mathrm{x}$ & $\mathrm{x}$ & $\mathrm{x}$ & $\mathrm{x}$ & $\mathrm{x}$ & $\mathrm{x}$ & $\mathrm{x}$ & $\mathrm{x}$ & $\mathrm{x}$ & $\mathrm{x}$ \\
\hline Equ. East. B. Crp (d) & NYC & n.a. & n.a. & - & - & 30 & 20 & $\mathrm{x}$ & $\mathrm{x}$ & $\mathrm{x}$ & $\mathrm{x}$ & $\mathrm{x}$ & $\mathrm{x}$ & $\mathrm{x}$ \\
\hline
\end{tabular}

Source: Kniffin 1921; New York Commercial 1922 and 1923 from Acceptance Bulletin. 1928 onwards from Acceptance Bulletin's Own League Tables. Mergers from Acceptance Bulletin and Variety of sources. 1917: May, 1922 \& 1923: Dec. 1927: Jan 1928. 1928, 1929, 1930, 1931, 1933, 1934, and 1935: Dec. of that year. 1932: Jan. 1933. 1936: Jun. (last issue of Acceptance Bulletin).

Notes

(a) After merger with American Exchange, becomes Irving Trust Cy

(b) Becomes Brown Brothers Harriman after merger with Harriman in 1933.

(c) Later, Bank of Manhattan Trust

(d) Subsidiary of Equitable Trust, merge with Chase at same date as Equitable Trust. 
Table 4. Determinants of Banks' Acceptances

Dependent variable: Ln (Acceptances Outstanding, bank $i, t$ )

OLS. All variables in logs, except Branching

Without clustering

\begin{tabular}{|c|c|c|c|c|c|c|c|}
\hline & \\
\hline & 1 & ॥ & III & IV & V & $\mathrm{VI}$ & VII \\
\hline - Total Assets/Liabilities & $0.90(12.19)$ & $0.72(13.53)$ & $0.73(13.21)$ & - & - & - & $0.59(3.91)$ \\
\hline - Capital, Surplus and Undivided Profits & - & - & - & $0.94(13.45)$ & $0.67(12.43)$ & $0.72(12.36)$ & $0.15(0.99)$ \\
\hline - US total trade (Exports+ Imports) & $0.68(4.70)$ & - & $0.08(0.68)$ & $0.83(5.86)$ & - & $0.25(2.10)$ & $0.12(1.01)$ \\
\hline - Total US acceptances outstanding & - & $1.05(12.72)$ & $1.03(11.61)$ & - & $0.96(11.10)$ & $0.88(9.37)$ & $0.99(10.34)$ \\
\hline - Branching & $0.30(2.41)$ & $0.57(6.09)$ & $0.55(5.71)$ & $0.32(2.66)$ & $0.64(6.79)$ & $0.58(5.79)$ & $0.54(5.53)$ \\
\hline - Intercept & $-8.92(-6.25)$ & $-8.77(-14.27)$ & $-9.36(-8.77)$ & $-8.35(-6.23)$ & $-6.37(-11.01)$ & $-8.25(-7.74)$ & $-9.27(-8.65)$ \\
\hline $\mathrm{N}$ & 262 & 249 & 249 & 263 & 250 & 250 & 249 \\
\hline Adjusted R & 0.51 & 0.72 & 0.72 & 0.55 & 0.70 & 0.71 & 0.72 \\
\hline
\end{tabular}

\section{With clustering}

\begin{tabular}{|c|c|c|c|c|c|c|c|}
\hline & \\
\hline & 1 & $\|$ & III & IV & V & $\mathrm{VI}$ & VII \\
\hline - Total Assets/Liabilities & $0.90(11.64)$ & $0.72(8.46)$ & $0.73(8.49)$ & - & - & - & $0.59(2.48)$ \\
\hline - Capital, Surplus and Undivided Profits & - & - & - & $0.94(13.15)$ & $0.67(8.43)$ & $0.72(8.70)$ & $0.15(0.73)$ \\
\hline - US total trade (Exports+ Imports) & $0.68(4.66)$ & - & $0.08(0.42)$ & $0.83(5.68)$ & - & $0.25(1.32)$ & $0.12(0.65)$ \\
\hline - Total US acceptances outstanding & - & $1.05(10.88)$ & $1.03(9.44)$ & - & $0.96(8.42)$ & $0.88(7.08)$ & $0.99(9.91)$ \\
\hline -Branching & $0.30(1.47)$ & $0.57(3.55)$ & $0.55(3.26)$ & $0.32(1.55)$ & $0.64(3.58)$ & $0.58(2.94)$ & $0.54(3.15)$ \\
\hline - Intercept & $-8.92(-6.96)$ & $-8.77(-16.28)$ & $-9.36(-6.39)$ & $-8.35(-6.20)$ & $-6.37(-9.36)$ & $-8.25(-4.98)$ & $-9.27(-6.35)$ \\
\hline $\mathrm{N}$ & 262 & 249 & 249 & 263 & 250 & 250 & 249 \\
\hline$\underline{\mathrm{R}}$ & 0.52 & 0.73 & 0.73 & 0.56 & 0.71 & 0.71 & 0.73 \\
\hline
\end{tabular}


Table 5. Determinants of Banks' Acceptances : Including Federal Reserve's Market Making Activities

Dependent variable: Ln (Acceptances Outstanding, bank i, t) Clustered standard errors. All variables in logs, except Branching With clustering

\begin{tabular}{|c|c|c|c|c|c|c|c|}
\hline & 1 & $\|$ & III & IV & $\mathrm{V}$ & $\mathrm{VI}$ & VII \\
\hline - Total Assets/Liabilities & $1.00(10.36)$ & $0.94(9.26)$ & $0.94(9.30)$ & - & - & - & $0.72(2.77)$ \\
\hline - Capital, Surplus and Undivided Profits & - & - & - & $0.97(15.72)$ & $0.92(11.60)$ & $0.93(11.83)$ & $0.24(1.05)$ \\
\hline - US total trade (Exports+ Imports) & $-0.09(-0.69)$ & - & $-0.10(-0.68)$ & $0.10(0.70)$ & - & $0.08(0.56)$ & $-0.04(-0.25)$ \\
\hline - Total US acceptances outstanding & - & $0.42(2.65)$ & $0.42(2.65)$ & - & $0.21(1.27)$ & $0.21(1.22)$ & $0.34(2.26)$ \\
\hline - Fed Acceptances/"own account" & $0.27(3.17)$ & $0.15(1.64)$ & $0.18(2.12)$ & $0.27(3.03)$ & $0.27(2.86)$ & $0.24(2.67)$ & $0.20(2.18)$ \\
\hline -Branching & $0.22(1.44)$ & $0.30(1.96)$ & $0.31(2.09)$ & $0.32(2.07)$ & $0.39(2.38)$ & $0.37(2.27)$ & $0.30(2.02)$ \\
\hline - Intercept & $-3.80(-3.31)$ & $-6.48(-8.99)$ & $-5.80(-5.64)$ & $-3.28(-2.83)$ & $-3.59(-3.72)$ & $-4.18(-3.63)$ & $-5.52(-5.37)$ \\
\hline$N$ & 205 & 205 & 205 & 206 & 206 & 206 & 205 \\
\hline$R_{-}$ & 0.72 & 0.74 & 0.74 & 0.71 & 0.72 & 0.72 & 0.74 \\
\hline
\end{tabular}

Table 6. Determinants of Banks' Acceptances : Including Federal Reserve's Own Market Making Activities and Holdings on Foreign Account.

Dependent variable: Ln (Acceptances Outstanding, bank $i, t$ ) Clustered standard errors. All variables in logs, except Branching With clustering

\begin{tabular}{|c|c|c|c|c|c|c|c|}
\hline & \\
\hline & 1 & II & III & IV & $\mathrm{V}$ & VI & VII \\
\hline - Total Assets/Liabilities & $0.90(10.00)$ & $0.83(8.84)$ & $0.83(8.76)$ & - & - & - & $0.66(2.80)$ \\
\hline - Capital, Surplus and Undivided Profits & - & - & - & $0.88(13.92)$ & $0.80(11.43)$ & $0.81(11.01)$ & $0.19(0.94)$ \\
\hline - US total trade (Exports+ Imports) & $-0.12(-0.77)$ & - & $-0.13(-0.83)$ & $0.12(0.72)$ & - & $0.08(0.50)$ & $-0.07(-0.45)$ \\
\hline - Total US acceptances outstanding & - & $0.53(3.66)$ & $0.54(3.66)$ & - & $0.41(2.71)$ & $0.40(2.59)$ & $0.49(3.67)$ \\
\hline - Fed Acceptances/"own account" & $0.22(12.71)$ & $0.14(4.35)$ & $0.14(5.14)$ & $0.19(9.00)$ & $0.14(4.33)$ & $0.14(4.59)$ & $0.15(5.19)$ \\
\hline -Branching & $0.31(1.95)$ & $0.40(2.51)$ & $0.42(2.57)$ & $0.36(2.15)$ & $0.47(2.76)$ & $0.45(2.49)$ & $0.40(2.48)$ \\
\hline - Intercept & $-2.76(-1.96)$ & $-6.59(-9.13)$ & $-5.45(-4.14)$ & $-2.62(-1.79)$ & $-3.77(-4.54)$ & $-4.48(-2.91)$ & $-5.31(-3.98)$ \\
\hline$N$ & 249 & 249 & 249 & 250 & 250 & 250 & 249 \\
\hline $\mathrm{R}_{-}$ & 0.74 & 0.76 & 0.76 & 0.73 & 0.74 & 0.74 & 0.76 \\
\hline
\end{tabular}


Table 7. Robustness: With Fed-Commercial Spread in place of Fed holdings

Dependent variable: Ln (Acceptances Outstanding, bank $i, t$ )

OLS. All variables in logs except Branching and Spread (Fed-Commercial). With clustering

\begin{tabular}{|c|c|c|c|c|c|c|c|}
\hline & \\
\hline & I & $\|$ & III & IV & $\mathrm{V}$ & $\mathrm{Vl}$ & VII \\
\hline 'otal Assets/Liabilities & $0.82(9.66)$ & $0.75(8.79)$ & $0.74(8.60)$ & - & - & - & $0.64(2.67)$ \\
\hline 'apital, Surplus and Undivided Profits & - & - & - & $0.84(12.08)$ & $0.73(9.44)$ & $0.73(8.85)$ & $0.12(0.57)$ \\
\hline JS total trade (Exports+ Imports) & $-0.71(-2.57)$ & - & $-0.35(-1.62)$ & $-0.27(-1.05)$ & - & $-0.04(-0.18)$ & $-0.30(-1.34)$ \\
\hline otal US acceptances outstanding & - & $0.92(7.47)$ & $0.89(8.20)$ & - & $0.75(6.00)$ & $0.75(6.41)$ & $0.86(8.54)$ \\
\hline ipread (Fed-Commercial) & $-0.92(-5.52)$ & $-0.15(-1.26)$ & $-0.36(-2.75)$ & $-0.71(-4.22)$ & $-0.24(-1.89)$ & $-0.26(-1.93)$ & $-0.35(-2.69)$ \\
\hline iranching & $0.42(2.63)$ & $0.52(3.14)$ & $0.54(3.22)$ & $0.42(2.47)$ & $0.56(2.95)$ & $0.57(2.90)$ & $0.53(3.13)$ \\
\hline \multirow[t]{3}{*}{ tercept } & $4.72(1.70)$ & $-7.97(-10.26)$ & $-4.46(-2.44)$ & $2.44(0.97)$ & $-5.02(-6.25)$ & $-4.61(-2.38)$ & $-4.56(-2.51)$ \\
\hline & 245 & 245 & 245 & 246 & 246 & 246 & 245 \\
\hline & 0.63 & 0.72 & 0.72 & 0.64 & 0.70 & 0.70 & 0.72 \\
\hline
\end{tabular}


Table 8. Robustness: Using log (Market Share) as dependent variable

\section{Dependent variable: Ln (Market Share, bank i, t) OLS. All variables in logs, except Branching With clustering}

\begin{tabular}{lccc} 
& \multicolumn{1}{c}{ I } & II & III \\
\hline - Total Assets/Liabilities & $0.72(8.67)$ & -- & $0.62(2.58)$ \\
- Capital, Surplus and Undivided Profits & -- & $0.67(8.80)$ & $0.11(0.53)$ \\
- Branching & $0.57(3.52)$ & $0.65(3.60)$ & $0.57(3.50)$ \\
- Intercept & $-8.45(-8.21)$ & $-6.64(-24.37)$ & $-8.24(-11.39)$ \\
\hline $\mathrm{N}$ & 249 & 250 & 249 \\
$\mathrm{R}$ & 0.66 & 0.63 & 0.66 \\
\hline
\end{tabular}

\section{Controlling for Federal Reserve Share}

\begin{tabular}{lccc} 
& \multicolumn{1}{c}{ I } & II & III \\
\hline - Total Assets/Liabilities & $0.77(9.47)$ & -- & $0.73(3.03)$ \\
- Capital, Surplus and Undivided Profits & - & $0.69(10.20)$ & $0.04(0.20)$ \\
- Branching & $0.50(3.20)$ & $0.61(3.41)$ & $0.50(3.19)$ \\
- Federal Reserve Share & $0.07(3.23)$ & $0.06(2.19)$ & $0.07(3.15)$ \\
- Intercept & $-8.58(-18.35)$ & $-6.62(-25.41)$ & $-8.50(-11.77)$ \\
\hline $\mathrm{N}$ & 249 & 250 & 249 \\
$\mathrm{R}_{-}$ & 0.68 & 0.65 & 0.68 \\
\hline
\end{tabular}




\section{References}

Aliber, Robert Z. (1966), The Future of the Dollar as an International Currency, New York: Frederick Praeger.

American Acceptance Council (1931), Facts and Figures Relating to the American Money Market, New York: American Acceptance Council.

American Acceptance Council (various years), Acceptance Bulletin, New York: American Acceptance Council.

Baster, A.S.J (1937), “The International Acceptance Market,” American Economic Review 27, pp. 294-304.

Battilossi, Stefano (2006), "The Determinants of Multinational Banking during the First Globalisation, 1880-1914”, European Review of Economic History 10, pp. 361-388

Briones, Ignacio and André Villela (2006), "European Bank Penetration during the First Wave of Globalisation: Lessons from Brazil and Chile, 1878-1913", European Review of Economic History 10, pp. 329-359

Broz, Lawrence (1997), The International Origins of the Federal Reserve System, Ithaca: Cornell University Press.

Cattani, Gino and Adrian E. Tschoegl, 2002 "An Evolutionary View of Internationalization: Chase Manhattan Bank, 1917 to 1996", Wharton School, Working Paper, 02-37.

Chinn, Menzie and Jeffrey Frankel (2008), "The Euro May over the Next 15 Years Surpass the Dollar as the Leading International Currency," International Finance (forthcoming).

Committee on Finance and Industry (1931), Report, London: HMSO.

Cleveland, Harold van B. and Thomas F. Huertas (1985), Citibank, 1812-1970, Cambridge, Mass.: Harvard University Press.

David, Paul (1985), "Clio and the Economics of QWERTY," American Economic Association Papers and Proceedings 75, pp.332-337.

Eichengreen, Barry and Marc Flandreau (2009), "The Rise and Fall of the Dollar, or When Did the Dollar Overtake Sterling as the Leading Reserve Currency?" European Review of Economic History 13, pp.377-411.

Ferderer, J. Peter (2003), "Institutional Innovation and the Creation of Liquid Financial Markets: The Case of Bankers' Acceptances, 1914-1934" Journal of Economic History 63, pp. 666-694. 
Flandreau, Marc and Clemens Jobst (2005). 'The Ties that Divide: a Network Analysis of the International Monetary System 1890-1910', Journal of Economic History 65, pp. 977-1007.

Flandreau, Marc and Clemens Jobst (2009), "The Empirics of International Currencies: Network Externalities, History and Persistence,” Economic Journal 119, pp.643-666.

Foulke, Roy Anderson. (1931), The Commercial Paper Market, New York: The Bankers' Publishing Company.

Greef, Albert O. (1938), The Commercial Paper House in the United States, Cambridge, Mass.: Harvard University Press.

Guaranty Trust Company of New York (1919), Acceptances, New York: Guaranty Trust Company.

Hausmann, Ricardo and Ugo Panizza (2010), "Redemption or Abstinence? Original Sin, Currency Mismatches, and Countercyclical Policies in the New Milenium," Center for Internatinal Development, Harvard University, Working Paper no. 194 (February).

Horesh, Niv (2008), “'Many a Long Day': HSBC and its Note Issue in Republican China," Enterprise and Society 9, pp. 6-43.

James, John (1995), "The Rise and Fall of the Commercial Paper Market, 1900-1930," in Michael Bordo and Richard Sylla (eds), Anglo-American Financial Systems, New York: Irwin, pp.219-260.

Jacobs, Lawrence M. (1910), Bank Acceptances, Washington, D.C.: Government Printing Office, 61st Congress, 2nd Session, Senate Doc. 569.

Jones, Geoffrey (1995), British Multinational Banking, 1830-1990, Oxford: Oxford University Press.

King, W.T.C. (1936), History of the London Discount Market, London: Routledge and Sons.

King, Frank (1989), History of the Hongkong and Shanghai Banking Corporation, Vol. 2, The Hong Kong Bank in the Period of Imperialism and War, 1895-1918, Cambridge: Cambridge University Press.

Kniffin., W. H., Jr. (1920), Commercial Paper, Acceptances, and the Analysis of Credit Statements: Practical Treatise on Commercial Paper, with Particular Reference to the Processes by which the Credit Risk is Determined where Such Instruments are Purchased as a Bank Investment, New York: Bankers Publishing Company (second edition).

Lewis, Cleona, (1938), America's Stake in International Investments, Washington DC: Brookings Institute. 
Liebowitz, Steven .J. and Stephen E. Margolis (1990), "The Fable of the Keys," Journal of Law and Economics 33, pp.1-25.

Lindert, Peter B. (1969), "Key Currencies and Gold 1900-1913," Princeton Studies in International Finance no. 24, International Finance Section, Department of Economics, Princeton University (August).

Mehrling, Perry (2010), The New Lombard Street: How the Fed Became the Dealer of Last Resort, Princeton: Princeton University Press.

Michie, Ronald (2007) "The City of London as a Global Financial Center," in Philip Cottrell, Evan Lange and Ulf Olsson (eds), Centres and Peripheries in Banking: The Historical Development of Financial Markets, London: Ashgate, pp.41-79.

Moulton, Brent R., 1990, "An Illustration of a Pitfall in Estimating the Effects of Aggregate Variables on Micro Units,” Review of Economic Studies, 72:2 (1990), 334-338.

Parrini, Carl (1969), Heir to Empire: U.S. Financial Diplomacy, 1916-1923, Pittsburgh: University of Pittsburgh Press.

Phelps, Clyde William (1927), The Foreign Expansion of American Banks, New York: Ronald Press.

Roberts, Richard and David Kynaston (2000) City State: How the Markets Came to Rule the World, London: Profile Books.

Robinson, Leland Rex (1923) Foreign Credit Facilities in the United Kingdom: A Sketch of Post-War Development and Present Status, New York: Columbia University Press.

Rothbard, Murray N. (1963), America's Great Depression, New York: Van Nostrand.

Robinson, Leland Rex, (1923), Foreign Credit Facilities in the United Kingdom. A Sketch of Postwar Development and Present Status, New York: Longman, Green.

Sayers, Richard S. (1968), Gilletts in the London Money Market, 1867-1967, Oxford: Clarendon Press.

Silber, William (2007), When Washington Shut Down Wall Street, Princeton: Princeton University Press.

Stallings, Barbara (1987), Banker to the Third World, Berkeley: University of California Press. Triffin, Robert (1960), Gold and the Dollar Crisis, New Haven: Yale University Press. 
Truptil, Roger, J. (1936), British Banks and the London Money Market, London: Jonathan Cape.

Vigreux, Pierre-Benjamin, (1932) Le crédit par acceptation: Paris centre financier, with a foreword by J. Velay. Paris: Librairie des Sciences Politiques et Sociales.

Warburg, Paul (1910), The Discount System in Europe, Washington: Government Printing Office, 61st Congress, 2nd Session, Senate Doc. 402. 


\section{Data Sources for Regression Analysis:}

US Banks data:

Extracted from $31^{\text {st }}$ December balance-sheet (or closest available date). Balance-sheets were collected from Baker Library (Harvard), Columbia University Library, British Library (London) and Graduate Institute Library (Geneva). The banks in the sample are as follows (periods for which we have data are indicated).

American Exchange Irving Trust 1927-1928

Bank of New York and Trust Company 1922-1938

Bank of the Manhattan Company 1924-1935 (missing years)

Bankers Trust Company 1915-1935

Central Hanover Bank and Trust Company 1930-1935

Chase Bank 1915-1938 (missing years)

Chemical Bank and Trust Company 1929-1935

Commercial National Bank and Trust Cy of NY 1929-1939

Continental Illinois National Bank and Trust Company 1932-1935

First National Bank of Boston 1915-1935

First National Bank of Chicago 1915-1935

Guaranty Trust 1914-1937

International Accpetance Bank 1929

Irving Bank-Columbia Trust Company 1920-1926

Manufacturers Trust Company 1924-1935

Marine Midland 1929-1935

National City Bank of new york 1915-1935

National Bank of Commerce in New York 1923-1928

Old Colony Trust Company 1919-1929 (missing years)

New York Trust Company 1920-1935

Philadelphia National Bank 1926-1935 (missing years)

Wells Fargo 1921-1935

Heavy Branching dummies:

Dummy equals 1 for Chase, First National Bank of Boston, Guaranty Trust, National City Bank

\section{Total Acceptances Outstanding:}

December totals from Acceptances Bulletin and Federal Reserve, as described in Text.

Federal Reserve Holdings of Acceptances (own and foreign accounts).

December observation from Federal Reserve Publications 